Review

\title{
Prosthodontic Applications of Polymethyl Methacrylate (PMMA): An Update
}

\author{
Muhammad Sohail Zafar 1,2,*(D) \\ 1 Department of Restorative Dentistry, College of Dentistry, Taibah University, Al Madinah, \\ Al Munawwarah 41311, Saudi Arabia \\ 2 Department of Dental Materials, Islamic International Dental College, Riphah International University, \\ Islamabad 44000, Pakistan
}

Received: 13 September 2020; Accepted: 2 October 2020; Published: 8 October 2020

\begin{abstract}
A wide range of polymers are commonly used for various applications in prosthodontics. Polymethyl methacrylate (PMMA) is commonly used for prosthetic dental applications, including the fabrication of artificial teeth, denture bases, dentures, obturators, orthodontic retainers, temporary or provisional crowns, and for the repair of dental prostheses. Additional dental applications of PMMA include occlusal splints, printed or milled casts, dies for treatment planning, and the embedding of tooth specimens for research purposes. The unique properties of PMMA, such as its low density, aesthetics, cost-effectiveness, ease of manipulation, and tailorable physical and mechanical properties, make it a suitable and popular biomaterial for these dental applications. To further improve the properties (thermal properties, water sorption, solubility, impact strength, flexural strength) of PMMA, several chemical modifications and mechanical reinforcement techniques using various types of fibers, nanoparticles, and nanotubes have been reported recently. The present article comprehensively reviews various aspects and properties of PMMA biomaterials, mainly for prosthodontic applications. In addition, recent updates and modifications to enhance the physical and mechanical properties of PMMA are also discussed.
\end{abstract}

Keywords: polymers; CAD/CAM PMMA; prosthesis; artificial teeth; dental base; prosthodontics; obturators

\section{Introduction}

A wide range of polymers are commonly used for various applications in clinical dentistry [1-8]. Amongst these, poly methyl methacrylate (PMMA) is a polymer that is most commonly used in dental laboratories (to make orthodontic retainers and dentures and for repair), dental clinics (for relining dentures and temporary crowns), and industry (such as fabrication of artificial teeth) $[7,9,10]$. Regardless of the intended application, PMMA is conventionally available in the form of a powder-liquid system. The powder contains a clear polymer (PMMA), however additives such as pigments and nylon or acrylic synthetic fibers are added to adjust the physical properties and aesthetics to mimic oral tissues (such as gums, mucosa). The liquid component contains a monomer of methyl methacrylate, along with cross-linking agents and inhibitors $[7,11,12]$.

PMMA gained popularity for various dental applications due to its unique properties, including its low density, aesthetics, cost-effectiveness, ease of manipulation, and tailorable physical and mechanical properties [9]. Although there are a number of concerns associated with using PMMA, such as the fracture of dentures due to water sorption and poor impact and flexural strength, the ongoing research has introduced a variety of modifications to overcome and further improve its properties (such as its conductivity, water sorption, solubility, impact and flexural strengths). For example, several studies reported the improvement of PMMA materials while reinforced using a variety of fibers [13-22], 
nanoparticles [23-37], and nanotubes [38-42]. Similarly, PMMA-based biocomposites with the addition of epoxy resins, polyamide, or butadiene styrene have been reported to improve the impact strength of PMMA [43]. The aim of the present article is to review various aspects of PMMA as a biomaterial for various dental applications. In addition, recent updates and modifications that have improved the material properties of PMMA are discussed.

\section{Historical Background and Development}

PMMA is an odorless polymer of acrylic acid that was reported by Redtenbacher for the first time in 1843 [44]. However, the development of PMMA for biomedical applications was a gradual process spread over a period of decades. Key stages during the development of PMMA for dental applications are shown in the Table 1. Since the 1940s, PMMA has become an essential biomaterial for dental laboratories and clinics.

Table 1. Chronology of the development of poly methyl methacrylate (PMMA) materials for dental applications.

\begin{tabular}{ccc}
\hline Year & Development & Reference \\
\hline 1843 & Formation of acrylic acid by oxidation of acrolein was reported & {$[44]$} \\
1931 & Harder PMMA became commercially available in sheet forms & {$[45]$} \\
1936 & Otto Rohm developed industrial PMMA as credit of their research in the beginning & {$[46]$} \\
1937 & PMMA was firstly introduced in powder form for denture base fabrication & {$[47]$} \\
1945 & PMMA was used extensively by neurosurgeons for cranioplasties & {$[48]$} \\
1945 & Cold-cured (room temperature curing) PMMA became commercially available & {$[49]$} \\
1946 & PMMA became the leading material for making dentures & {$[47]$} \\
1950 s & Orthopedic surgeon used PMMA for the cementation of femoral bones prostheses & {$[48]$} \\
1950s to 1960s & PMMA's use by dental professionals dramatically increased for a variety of & {$[50]$} \\
& applications, including dentures, temporary or provisional crowns, & and maxillofacial prostheses \\
21st century & Ongoing research and modifications of existing PMMA materials are improving & {$[51-54]$} \\
\hline
\end{tabular}

Due to the acquired properties, such as the ease of processing, acceptable mechanical properties, aesthetics [55], cost-effectiveness, and relatively lower toxicity [56-58], PMMA has replaced previously used denture base materials (Table 2). All previously used denture base materials had certain disadvantages, and the search for an ideal denture base material is still ongoing. During the last half of 20th century, PMMA not only took over other denture base materials but also obtained remarkable popularity for the manufacturing of various dental and maxillofacial prostheses, including obturators, dentures, temporary crowns, and bridges, [50].

Table 2. Key advantages and disadvantages of various denture base materials replaced by PMMA.

\begin{tabular}{ccc}
\hline Material & Advantages & Disadvantages \\
\hline Gold & $\begin{array}{c}\text { Gold is known for its excellent biocompatibility and } \\
\text { corrosion resistance. Denture base was historically } \\
\text { fabricated using gold centuries ago [59-61]. }\end{array}$ & $\begin{array}{c}\text { Expensive, poor aesthetics due to its color } \\
\text { [60]. }\end{array}$ \\
\hline Porcelain & $\begin{array}{c}\text { Porcelain was introduced in the 18th century for } \\
\text { denture fabrication [60]. }\end{array}$ & $\begin{array}{c}\text { Very hard, high-density brittle materials } \\
\text { with poor aesthetics [57]. }\end{array}$ \\
\hline Vulcanite & $\begin{array}{c}\text { Vulcanite is a cost-effective material that was } \\
\text { introduced in the 19th century and used for several } \\
\text { years; vulcanite is dimensionally stable, comfortable, } \\
\text { low density, light weight, and is easily fabricated [60]. }\end{array}$ & $\begin{array}{c}\text { Absence of chemical bonding with } \\
\text { porcelain teeth and poor aesthetics [55]. }\end{array}$ \\
\hline Aluminum & $\begin{array}{c}\text { Aluminum was used to cast denture bases using a } \\
\text { casting process during the 19th century [60], providing } \\
\text { accurate fit and light weight [57]. }\end{array}$ & $\begin{array}{c}\text { Casting aluminum was an expensive and } \\
\text { sensitive technique [57]. }\end{array}$ \\
\hline
\end{tabular}


Table 2. Cont.

\begin{tabular}{|c|c|c|}
\hline Material & Advantages & Disadvantages \\
\hline Celluloid & $\begin{array}{l}\text { A polymeric material used in the 19th century; can be } \\
\text { colored pink to mimic oral tissues [45]. }\end{array}$ & $\begin{array}{l}\text { Color changes by staining from food and } \\
\text { altered taste due to the presence of } \\
\text { camphor [45]. }\end{array}$ \\
\hline Bakelite & Used in the 20th century; had excellent aesthetics [57]. & $\begin{array}{l}\text { Difficult manipulation, prone to staining, } \\
\text { and brittle [57]. }\end{array}$ \\
\hline $\begin{array}{l}\text { Polyvinyl } \\
\text { Chloride } \\
\text { (PVC) }\end{array}$ & $\begin{array}{l}\text { A co-polymer of acetate and vinyl chloride used for } \\
\text { dentures in the 20th century [62]. }\end{array}$ & $\begin{array}{l}\text { Poor mechanical properties and prone to } \\
\text { discoloration [62]. }\end{array}$ \\
\hline $\begin{array}{l}\text { Base metal } \\
\text { alloys }\end{array}$ & $\begin{array}{l}\text { Nickel and cobalt chromium alloys have been used } \\
\text { since early 20th century. Still used due to their } \\
\text { excellent mechanical properties, low density, } \\
\text { and cost-effectiveness [57]. }\end{array}$ & $\begin{array}{l}\text { Poor aesthetics due to metallic color, very } \\
\text { hard materials; difficult to cut, finish, } \\
\text { and repair. There are allergy issues } \\
\text { mainly due to the presence of nickel [57]. }\end{array}$ \\
\hline
\end{tabular}

However, PMMA is not an ideal material due to discrepancies in its physical and mechanical characteristics. For instance, PMMA absorbs water, which may compromise its physical and mechanical properties while in use [63,64] and make it vulnerable to failure under cyclic loading [65]. Currently, a number of researchers are focused on mechanical reinforcement $[30,38,51,53,66-74]$ and chemical modification $[53,75,76]$ of PMMA to overcome its drawbacks and improve its properties, which have been reviewed in this article. In order to better understand and interpret these recent modifications, it is important to understand the chemistry, types, and properties of PMMA materials.

\section{Chemistry and Types of PMMA}

PMMA (IUPAC name: poly [1-(methoxy carbonyl)-1-methyl ethylene]) is a synthetic polymer prepared by the free radical addition and polymerization of methyl methacrylate $\left(\mathrm{C}_{5} \mathrm{O}_{2} \mathrm{H}_{8}\right)$ to poly methyl methacrylate $\left(\mathrm{C}_{5} \mathrm{O}_{2} \mathrm{H}_{8}\right)_{n}$ [77]. The polymerization reaction is initiated and activated by generating a free radical either chemically or with energy (such as heat, light, microwaves). In the propagation stage, the activated polymerization continues via the binding of monomers followed by termination through shifting of the free electrons to the chain end.

There are various mechanisms that can terminate the polymerization reaction, such as the addition of chemical inhibitors (hydroquinone or methyl-ether) to the monomer. Similarly, any impurities present in the monomer may inhibit the polymerization by reacting with the free radicals [78]. According to the American Dental Association (ADA) Specification No. 12 [79,80], the denture base polymers are classified into various types and classes (Figure 1). Based on the activation of the polymerization reaction, there are three main types of denture base polymers [11], which may differ from each other in terms of their polymerization reactions and compositions (Figure 1).

In addition to types I, II, and III (based on ADA specifications), the ISO 20795-1 2013 further included light-activated (type IV) and microwave-cured (type V) polymers [81]. The characteristics of various types of PMMA denture base materials are compared in the following section. 


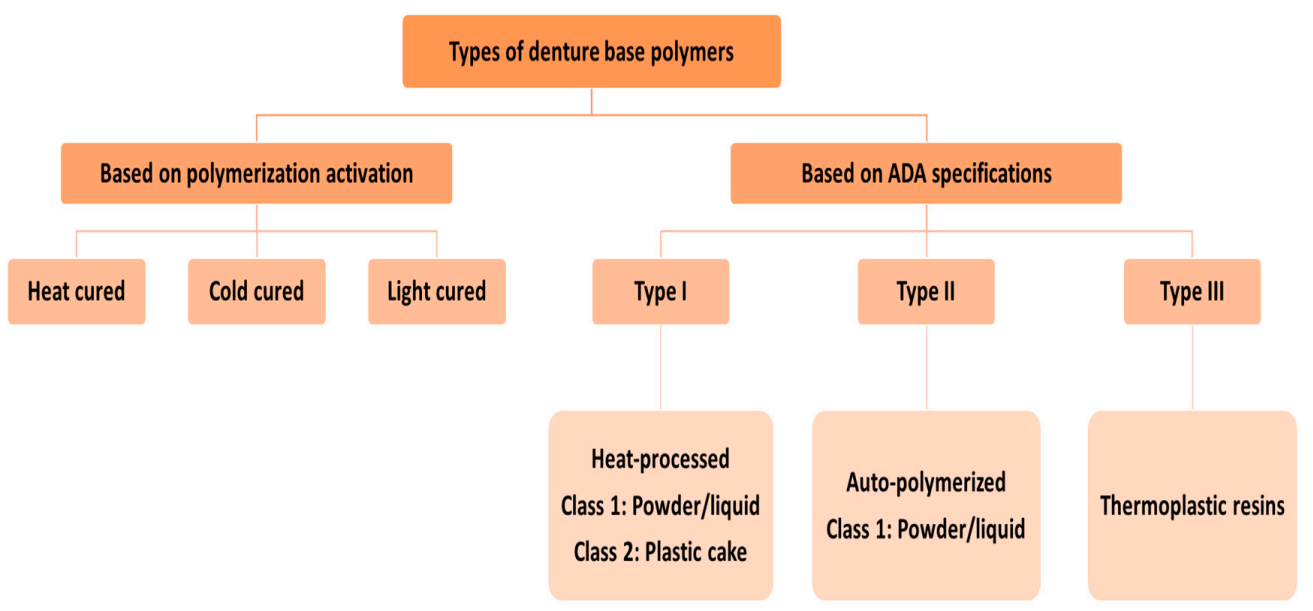

Figure 1. Classification of denture base polymers based on polymerization activation and according to the ADA specifications.

\subsection{Heat-Cured PMMA}

Heat curing PMMA materials are available in powder and liquid forms and commonly used for making denture bases and dentures [78]. PMMA powder contains PMMA, benzoyl peroxide initiator, a plasticizer (dibutyl phthalate), opacifiers (titanium and zinc oxides), fibers, and pigments or dyes. The liquid component contains methyl methacrylate (MMA) monomer, ethylene glycol dimethacrylate as a cross-linking agent, and hydroquinone as an inhibitor [10]. The polymerization reaction starts upon mixing of both components and requires heat energy (such as from a water bath) to activate the initiator. These materials contain benzoyl peroxide as an initiator, which dissociates into carbon dioxide $\left(\mathrm{CO}_{2}\right)$, generating free radicals upon heating [82]. A high degree of polymerization results in good physical properties; however, polymerization and poor adaptation remain the main concerns [78]. Various combinations of heat curing cycles can be used for both compression and injection molding (Table 3).

Table 3. Various heat cycles used for the polymerization of heat-cured PMMA.

\begin{tabular}{ccccc}
\hline Heat Cycles & Temperature & Time & Terminal Boiling & Reference \\
\hline 1 & $74^{\circ} \mathrm{C}$ & $8 \mathrm{~h}$ & None & {$[78]$} \\
2 & $74^{\circ} \mathrm{C}$ & $8 \mathrm{~h}$ & $1 \mathrm{~h}$ & {$[78]$} \\
3 & $74^{\circ} \mathrm{C}$ & $3 \mathrm{~h}$ & $1 \mathrm{~h}$ & {$[78]$} \\
4 & $73.9^{\circ} \mathrm{C}$ & $12 \mathrm{~h}$ & None & {$[50]$} \\
5 & $70^{\circ} \mathrm{C}$ & $3 \mathrm{~h}$ & $1 \mathrm{~h}$ & {$[83]$} \\
6 & $100^{\circ} \mathrm{C}$ & $20 \mathrm{~min}$ & None & {$[84]$} \\
\hline
\end{tabular}

The typical heat curing cycle involves a longer curing time $\left(\sim 9 \mathrm{~h}\right.$ at $\left.74{ }^{\circ} \mathrm{C}\right)$; alternatively, rapid-heat-polymerized PMMA requires a significantly shorter $\left(20 \mathrm{~min}\right.$ at $\left.100{ }^{\circ} \mathrm{C}\right)$ curing time [84]. The polymerization process in the latter type is accelerated due to the presence of heat and chemically activated initiators in the composition [85]. The main purpose of the heating cycle is to achieve a high degree of polymerization and decrease residual monomers in the cured prothesis.

\subsection{Microwave-Cured PMMA}

Microwave energy is another source of heat energy that can be used to polymerize and cure PMMA. Instead of using a conventional water bath, a source of microwave energy and a non-metallic denture flask are required to polymerize these denture base materials [9]. Microwave curing has the main benefit of time effectiveness due to a short curing time (three minutes) at $500 \mathrm{w}$ in a microwave $[84,86]$, as compared to the conventional heat curing cycle, which require hours of heating followed by a cooling down period. The physical properties, including the dimensional accuracy of microwave 
PMMA materials, are comparable to conventional heat-cured PMMA [9]. A previous study [86] compared conventional heat-cured PMMA, injection-molded PMMA, and compression-molded and microwave-cured PMMA. It was reported that the impact and flexural strengths of injection-molded, microwave-cured PMMA were inferior to conventional heat-cured PMMA [86]. The benzoyl peroxide initiator is not present in microwave-cured PMMA, so therefore these materials cannot be cured using a conventional water bath heating cycle [86]. The main limitation of the microwave-cured PMMA materials is their weak bond strength with the acrylic teeth, which limits their prosthodontic applications [9]. In addition, the equipment and non-metallic flasks are comparatively expensive and are likely to fracture following cyclic loadings with excessive packing pressure [87].

\subsection{Cold-Cured PMMA}

Cold-cured PMMA (also known as chemically cured or auto-polymerizing PMMA) has a distinct composition and mechanism of polymerization compared to heat-cured PMMA and does not require thermal energy. A tertiary amine initiator such as dimethyl-p-toluidine [82] is added to the cold-cured PMMA, which activates the benzyl peroxide, chemically generating free radicals to initiate the polymerization [88]. However, the degree of polymerization of cold-cured PMMA is remarkably lower than heat-cured PMMA, leaving uncured residual monomers in the polymerized material, which tend to leach out [78]. Compared with heat-cured PMMA, the main advantages of cold-cured PMMA include its better dimensional stability and adaptation, resulting in minor polymerization shrinkage [78,82] however a lesser degree of polymerization [82]. However, the poor degree of polymerization compromises the mechanical properties, such as the strength and hardness [87]. In addition to monomer leaching and inferior mechanical properties, the amine initiator oxidizes with time, resulting in discoloration [82], poor color stability, and lower glass transition temperature [89]. Due to these limitations, currently cold-cured PMMA materials are only used for fabricating custom trays and provisional partial dentures and for denture repair [78]. Recently, Alqahtani [73,90] modified cold-cured PMMA to improve the mechanical properties. The addition of a hexagonal boron nitride nanopowder enhanced the elastic modulus and bending strength, while adding zirconia $\left(\mathrm{ZrO}_{2}\right)$ increased the surface hardness. Furthermore, it was speculated that the hybrid reinforcement using $\mathrm{ZrO}_{2}$ and hexagonal boron nitride may remarkably improve the strength and stiffness of PMMA for durable fabrication of crowns, fixed dentures, and repairs [90]. Due to the presence of a greater amount of residual monomers and the heat resulting from exothermic polymerization, cold-cured PMMA materials are not considered for long-term oral applications.

\subsection{Light-Cured PMMA}

Light-cured (also known as visible-light-cured) PMMA works similarly to the resin-based restorative composites, which are cured when exposed to visible light [91,92]. The PMMA is modified by replacing the conventional initiator with a photo-sensitive agent (camphorquinone), which is activated and generates free radicals upon exposure to light. The light-cured PMMA materials are supplied in pre-mixed form containing PMMA fillers, silica, urethane dimethacrylate matrix, and acrylic resin monomers. To cure PMMA completely, the materials must be exposed to visible light for the required duration of time following adaptation in the cast and teeth placement. Following the polymerization, the light-cured PMMA can be finished and polished similarly to conventional heat-cured PMMA [78]. The light-cured PMMA has the advantages of easier fabrication and allowing full control over of curing, providing sufficient time for the manipulation and adaptation before initiating the polymerization [9]. Additionally, polymerization shrinkage, the existence of residual monomers, and bacterial adhesion are reduced compared to with heat- and cold-cured PMMA materials, which are the potential benefits of light-cured PMMA [93]. However, light-cured PMMA materials are not used commonly due to their drawbacks, such as their limited curing depth, technique sensitivity, and cost [87]. The mechanical properties of light-cured PMMA materials are slightly inferior to conventional PMMA [94], and therefore their applications are limited to relining and repair of denture 
bases [10], in addition to fabrication of custom trays and base plates for complete dentures. It is obvious that each type of PMMA material differs in terms of its composition, polymerization, benefits, and drawbacks. Accordingly, no single type can be labelled as the superior material for all dental applications. Therefore, dental teams should consider the characteristics and suitability of each type of PMMA when selecting a material for a specific application.

\section{Manipulation}

The majority of PMMA formulations are supplied as polymeric powders and colorless monomer liquids (Figures $2 \mathrm{a}$ and $2 \mathrm{~b}$, respectively). The exothermic chemical reaction starts upon mixing of the PMMA powder and liquid, which harden either chemically (cold cure) or via energy application in the case of heat-cured PMMA materials [7,11]. The typical process of PMMA polymerization (initiation, activation, propagations, and termination) is described in Section 3. To avoid any discrepancies, it is necessary to use the recommended ratio of PMMA powder and liquid (2.5:1 w/v or 3-3.5:1 v/v). In the case of a high powder-to-liquid ratio, this means that not all of the PMMA beads will be wet, leading to a granular texture, while a low powder-to-liquid ratio enhances polymerization shrinkage and dimensional changes [9]. Depending on the consistency, the manipulation of PMMA mixing can be divided into distinct stages (such as sandy, stringy, doughy, rubbery, and stiff stages), which are followed by packing and finishing of denture bases (Figure 2).

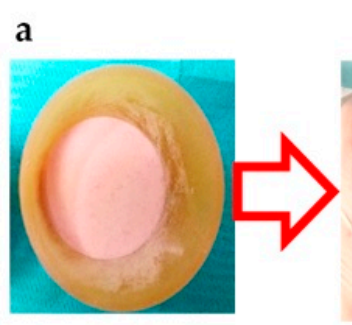

\section{b}

c

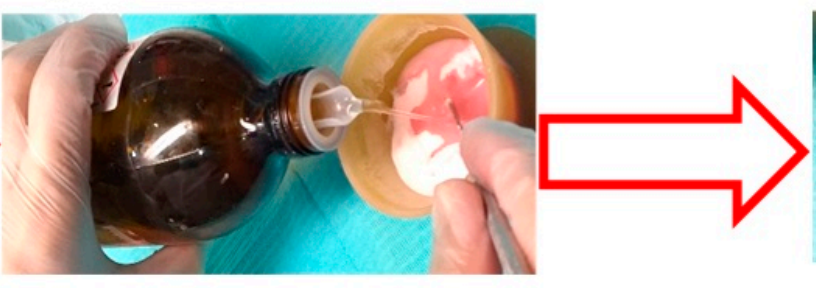

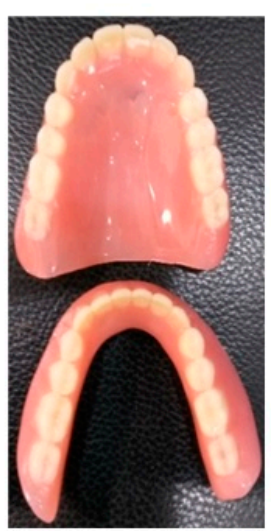

h

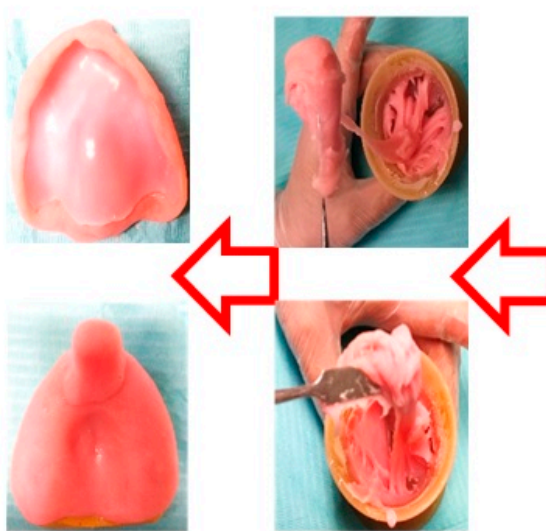

g f

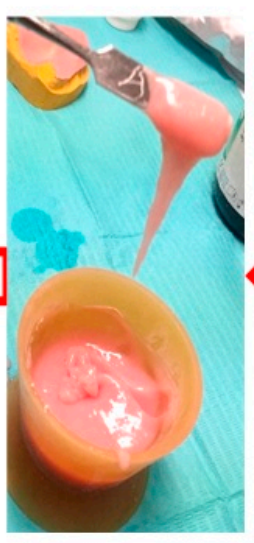

e

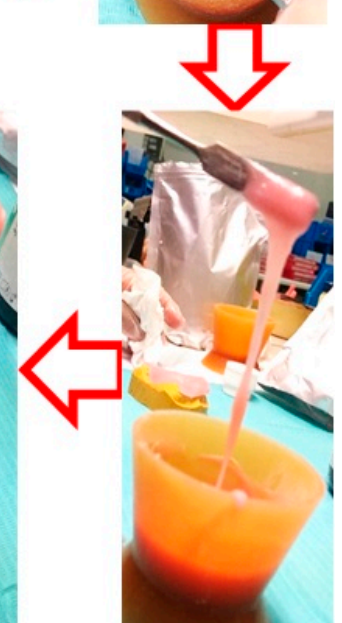

d

Figure 2. Manipulation and various stages of PMMA manual mixing and handling for denture fabrication: (a) PMMA powder in a mixing bowl; (b) pouring of the monomer solution into PMMA for mixing; (c) sandy stage, whereby the monomer solution has full wetted and saturated the PMMA particles; (d) start of stringy stage; (e) progression of the stringy stage; (f) dough stage ready for packing and plastic molding; (g) rubbery stage followed by the hardened PMMA, whereby plastic deformation is no longer possible; (h) fabricated denture using heat-cured PMMA and acrylic teeth after finishing and polishing.

The mixing process starts with the sandy stage (Figure 2c), in which the monomer wets the PMMA granules, giving the mixture a grainy appearance. There is hardly any chemically interaction or polymerization during this stage [32]. In the stringy stage, the monomer molecules attack and 
dissolve PMMA particles and disperse the polymer chains in the liquid phase. At the same time, the larger PMMA particles begin to unfold and enhance the viscosity [95]. Typically, the stringy stage is characterized by formation of sticky strings upon touching or stretching (Figure 2d,e), further progresses to the doughy stage (Figure 2f). However, the mixture still contains a number of undissolved polymer chains. This stage is characterized by the loss of stringiness and stickiness [95]. In addition, the mixture in the doughy stage is considered suitable for packing into a dental flask (Figure 2f). The dough-forming time (from mixing to doughy stage) is affected by various factors, such as the polymer's molecular weight, the particle size and surface area, temperature, the presence of a cross-linking agent or plasticizer, and the powder-liquid ratio [82]. The doughy stage progress to the rubbery stage by further conversion of monomers into polymers and evaporation of the residual monomers. This stage is characterized by the rubbery appearance of the matrix (which rebounds after releasing compressive or tensile stresses) and its inability to be packed into the compression molds. In the stiff stage, the continuation of polymerization and further evaporation of monomers results in hardening and reinforcement of mechanical properties (Figure 2g). The polymerized PMMA become dry, stiff, and resistant to plastic deformation [9]. Alternatively, PMMA powder and monomers can be mixed using ultrasonic mixing. Although the ultrasonic mixing of modified PMMA has been shown to be superior in terms of texture and packing [73], its use is limited in dental laboratories due to the requirement of additional equipment and the associated costs.

For the prosthesis fabrication, the PMMA in the dough stage is packed into specialized dental flasks under compression. Due to the method's accuracy and cost-effectiveness, compression molding is frequently used for producing heat-cured PMMA prostheses [96,97]. The dental flask packed with PMMA is heated in a water bath under the defined time and temperature conditions (Table 3). To ensure proper polymerization, the temperature of the water bath should be increased gradually. Immersion of the dental flask directly into boiling water results in evaporation of the monomer (boiling point $100.3^{\circ} \mathrm{C}$ ) prior to polymerization and enhanced porosity in the cured material [88]. Alternatively, the injection molding technique can also be used to fabricate dentures, which requires the use of specially designed dental flasks with a sprue. The denture base material is injected through the sprue hole while the vent hole facilitates the escape of hot gasses [88]. Following the injection of heat-cured PMMA, the heat curing process is started. The polymerization shrinkage is compensated for by continuously injecting the PMMA during the curing process [78]. For both compression and injection molding, similar heat curing cycles can be used, as shown in Table 3. Considering the mismatch of the thermal expansion coefficients of PMMA and investment plaster, it is advised to cool down the dental flask to room temperature gradually to avoid distortion of the denture base. It is recommended to remove the flask from the water bath to allow bench cooling for half an hour, followed by immersion in tap water (15 min) prior to opening [78]. The PMMA dentures should be finished and polished before use in the oral cavity [98].

\section{Properties of PMMA}

The PMMA-based materials should have certain desired properties depending on the biological application. Accordingly, PMMA materials have been extensively modified and explored in relation to various chemical [77,99], biological [77,100-102], physical [70,77,103], and mechanical properties [66,68,70,100,103-105]. Primarily, it is important to understand the ideal or desired properties of PMMA materials for denture base applications (Figure 3).

Prosthodontic restorations need to be performed in complex oral environments (biofunctionality) without exerting any adverse effects on the surrounding tissues. Therefore, the PMMA used for denture base materials should be biocompatible and should not cause any irritation, toxicity, or mutagenicity to the oral tissues $[78,106]$. Chemically, PMMA needs to be highly insoluble in saliva and oral fluids. It should be non-reactive to nutrients, however should chemically bond to artificial teeth. Additionally, the PMMA should have good mechanical properties (such as high elastic modulus, proportional limit, resilience, fatigue strength, and impact strength) to withstand the forces of 
mastication without failure $[78,106]$. In addition, other properties such as having low specific gravity (light weight), thermal conductivity, ease of cleaning, and low cost are favorable for patient comfort $[78,106]$. The key properties of PMMA are presented in the Table 4 and discussed in the following sections.

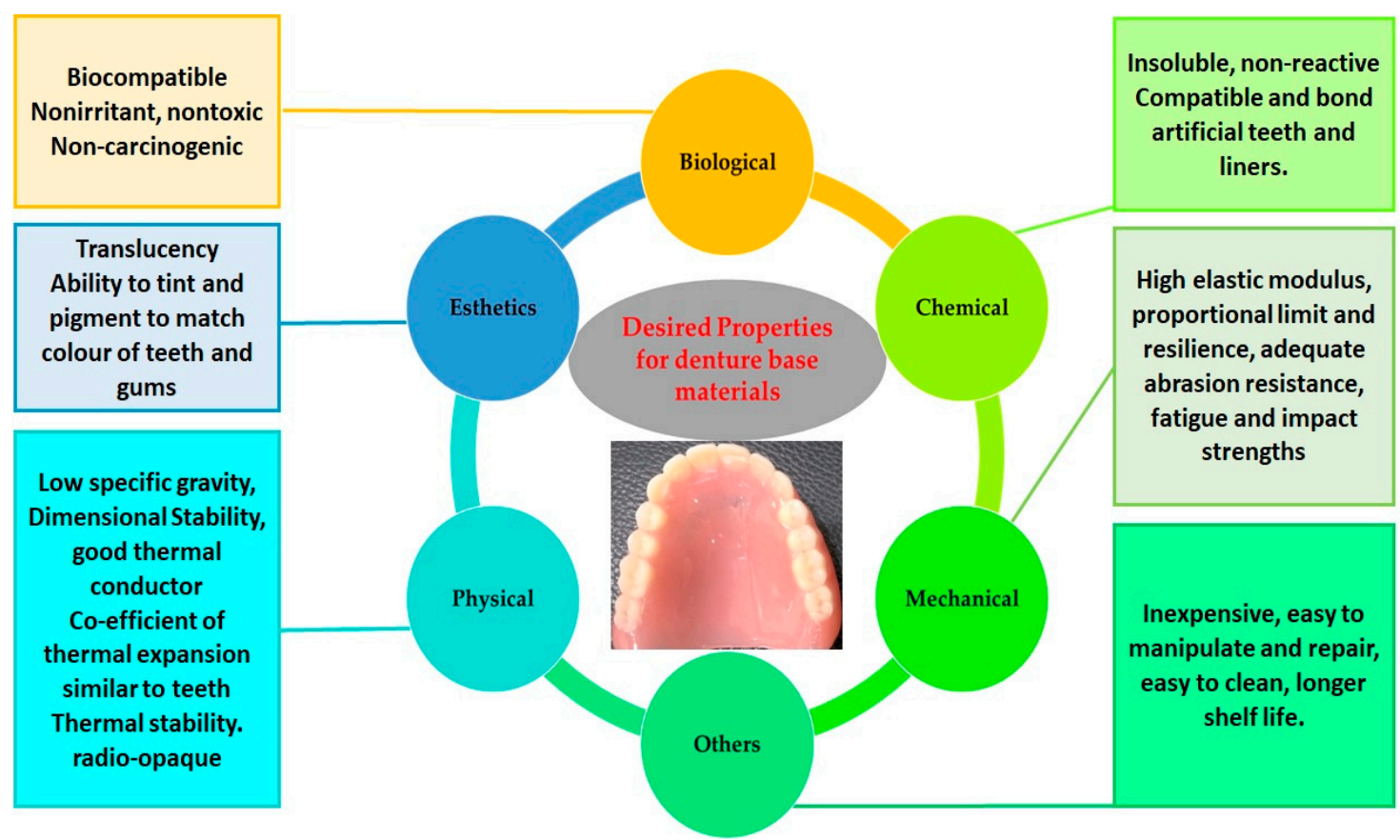

Figure 3. Ideal properties required for the PMMA materials for denture base applications.

Table 4. Various properties of heat-cured PMMA.

\begin{tabular}{|c|c|c|}
\hline Property & Value & Reference \\
\hline Elastic modulus (GPa) & $\begin{array}{c}2.6 \\
3.89+130\end{array}$ & [7] \\
\hline Flexural strength $(\mathrm{MPa})$ & 90 & {$[7]$} \\
\hline Fracture toughness $\left(\mathrm{MN} / \mathrm{m}^{3 / 2}\right)$ & 2.53 & [7] \\
\hline Fracture toughness (MPa.m¹/2) & $1.86 \pm 0.25$ & [66] \\
\hline Proportional limit (MPa) & 26 & [82] \\
\hline Compressive strength (MPa) & 76 & [82] \\
\hline & $48-62$ & [82] \\
\hline lensile strength (MPa) & 55 & [7] \\
\hline Elongation (\%) & $1-2 \%$ & [82] \\
\hline Impact strength $(\mathrm{J})$ & $0.98-1.27 \mathrm{~J}$ & {$[66,82]$} \\
\hline Knoop hardness (KHN) & 18-20 KHN & [82] \\
\hline Rockwell hardness & M90-M100 & {$[107,108]$} \\
\hline Vickers hardness (VHN) & 20 & [7] \\
\hline Absolute hardness (MPa) & $297.72 \pm 19.04$ & [98] \\
\hline Fatigue strength $(\mathrm{MPa})$ & $1.5 \times 10^{6}$ cycles at $17.2 \mathrm{MPa}$ & [82] \\
\hline Biaxial flexural strength & $121 \pm 12$ & [66] \\
\hline Thermal conductivity & $5.7 \times 10^{-4}{ }^{\circ} \mathrm{C} / \mathrm{cm}$ & [82] \\
\hline Coefficient of thermal expansion & $81 \times 10^{-6} /{ }^{\circ} \mathrm{C}$ & [82] \\
\hline Linear thermal expansion $(\mathrm{mm} / \mathrm{mm} \cdot \mathrm{k})$ & $6.3 \times 10^{-5}$ & [108] \\
\hline Glass transition temperature & $125^{\circ} \mathrm{C}$ & {$[7,82]$} \\
\hline Curing shrinkage (\%) & -0.50 to -0.58 & [95] \\
\hline Density $\mathrm{g} / \mathrm{cm}^{3}$ at room temperature & 1.18 & {$[107,108]$} \\
\hline Sorption $\left(\mathrm{mg} / \mathrm{cm}^{2}\right)$ & 0.69 & [82] \\
\hline Solubility $\left(\mathrm{mg} / \mathrm{cm}^{2}\right)$ & 0.02 (water), 0.04 (hydrocarbons) & [82] \\
\hline Color & Transparent, colorless & [7] \\
\hline
\end{tabular}




\subsection{Biological Properties of PMMA}

Biocompatibility is the most important biological property, which is defined as a material's ability to perform in a biological environment with a favorable host response [56]. Although there are very limited biocompatibility issues for properly fabricated heat-cured PMMA, the presence of uncured or residual monomers in the cured denture base has been reported to be associated with mucosal irritation [109], tissue inflammation, and cytotoxicity [110,111]. Therefore, adding a larger amount of monomer solution while mixing PMMA leaves residual monomers and results in corresponding cytotoxicity [58]. In addition to a low monomer-polymer ratio, an extended polymerization cycle also decreases the residual monomer quantity and cytotoxicity compared to short curing cycles [112]. As a comparison, heat-cured and microwave-cured PMMA eluted significantly lower amounts of monomers and cytotoxicity compared to cold-cured PMMA [101]. The immersion in water prior to use considerably reduced the residual monomer amount, as well as the cytotoxicity of PMMA [112]. In addition to biocompatibility, the excessive amount of residual monomers is also directly related to the solubility of PMMA denture base materials, as the leaching of unreacted monomers enhances the degree of solubility $[113,114]$. Therefore, the amount of residual monomers and the cytotoxicity of the PMMA denture base can be controlled by enhancing the degree of polymerization using heat-cured PMMA and the recommended heat curing cycle [110]. Accordingly, properly cured PMMA materials with low amounts of monomers are likely to have good biocompatibility. The volatile nature of monomers and the dusty nature of the fine PMMA particles may result in professional hazards to the dental staff who are involved in the handling of this material [115]. To reduce the concentration of monomer vapors and exposure in dental clinics and laboratories, appropriate safety measures such as the use of personal protection (mask, gloves) and airtight containers, good ventilation, and quick disposal of any spills should be practiced. In addition, dental staff should be educated about the toxic and volatile nature of monomer solution (no exposure to flames) and immediate washing of the skin if exposed to the monomer solution [115].

\subsection{Physical Properties of PMMA}

PMMA materials have favorable physical properties for denture base applications. Sorption (water or oral fluid uptake) takes place while they are immersed [116]. Due to the molecular polarity, the water molecules infiltrate through the polymer chains and act as plasticizers [117]. In addition, the penetrated water molecules lead to the expansion of the PMMA and affect the dimensional stability [64]. Another related property is the solubility, which may affect the dimensional stability $[116,118]$. Therefore, the sorption and associated solubility should be kept to a minimum. According to ISO 20795-1 [81], the sorption and solubility should be less than 32 and $1.6 \mu \mathrm{g} / \mathrm{mm}^{3}$, respectively. Several studies $[119,120]$ have reported that the sorption and solubility of the currently available PMMA denture base materials are well below the required values required by ISO 20795-1 [81]. The sorption and solubility of heat-cured PMMA materials are lower compared to cold-cured PMMA materials [119]. Considering that the sorption and solubility are directly associated with the residual monomer quantity present in the prosthesis, heat-cured PMMA materials demonstrate a greater degree of polymerization, less residual monomers, and better physical properties compared to cold-cured PMMA.

The denture base materials should have acceptable thermal conductivity to conduct the temperature of food to the patients' oral tissues. However, the thermal conductivity of PMMA is low $\left(5.7 \times 10^{-4}{ }^{\circ} \mathrm{C} \cdot \mathrm{cm}^{-1}\right)$ [82]; therefore, heat produced during the denture fabrication is dissipated slowly and results in surface crazing. The low conductivity can also affect a patient's ability to sense the food temperature as compared to metallic denture bases, which are highly conductive compared to PMMA. Hot drinks may reach the pharynx or esophagus without being noticed and may burn the delicate mucosa [121]. To fulfill the aesthetic requirements, PMMA denture base materials should mimic the oral mucosa in terms of color, hue, and texture. Various transparent pigments can be added to PMMA to achieve provide good aesthetic properties, mimicking the patient's natural tissues 
(Figure 2h). Additionally, the denture base materials should have high color stability and should not change (discolor) in the oral environment over time [122]. However, PMMA-based materials have demonstrated poor color stability and tend to change while functioning due to several factors. The release of residual monomers enhances the water sorption and discoloration due to ingress of various molecules. Other factors associated with staining and color changes of PMMA include the fabrication porosity and periodic consumption of various beverages such as coffee, tea, carbonated drinks, and alcohol $[123,124]$. Therefore, PMMA dentures may require replacement after a period of time due to inferior wear resistance, staining, and poor aesthetic properties.

The polymerization shrinkage (linear and volumetric) may result in remarkable dimensional changes and inaccuracies during denture fabrication [78]. Therefore, the lowest level of polymerization shrinkage is desired for dental applications. Comparing various types of PMMA, light-cured PMMA has demonstrated lower amounts of residual monomers and less polymerization shrinkage compared to heat- and cold-cured PMMA materials [93]. In terms of heat-cured PMMA, the injection molding technique has been suggested to reduce polymerization shrinkage and improve the marginal seal, as compared to conventional compression molding [96,125]. In the injection molding technique, continuous injection of the PMMA compensates for the polymerization shrinkage [78]. Additionally, various modifications of PMMA, such as reinforcement using fibers $[76,126]$ or carbon nanotubes [41], can remarkably decrease the polymerization shrinkage and dimensional accuracy of the dental prostheses. Radiopacity is another physical property that is ideally required in restorative dental materials. Radiopaque restorative materials appear white and can easily be distinguished from tissues in diagnostic radiographs. For example, in case a broken piece of a denture is accidently swallowed, radiopaque objects can be detected easily $[127,128]$. Due to its polymeric nature, PMMA is a radiolucent material that is hard to detect in radiographs [129]. Inducing radiopacity by modification is challenging, as most heavy metal salts are not compatible with PMMA [7]. The incorporation of various heavy metals has been explored to enhance the radiopacity [130,131]. Although various modifications have improved the radiopacity of PMMA to some extent, there are certain concerns, such as a lack of physical or chemical binding of additives to the matrix and the salts being prone to leaching out of the denture base $[132,133]$. Similarly, adding heavy metal salts improved the radiopacity in one study, however various properties, including the polishability, bonding strength, and aesthetic properties, were significantly affected [133]. In contrast, Lang et al. [130] incorporated triphenylbismuth $(30 \% w / w)$ into PMMA and reported sufficient radiopacity without compromising the mechanical and aesthetic properties. The modification of PMMA materials by adding radiopaque agents without compromising the aesthetic and mechanical properties is challenging and requires further research.

\subsection{Mechanical Properties of PMMA}

Denture base materials are exposed to complex masticatory stresses in the oral cavity. Therefore, good mechanical properties are required for the functional performance of denture base materials (biofunctionality). Considering the significance of the mechanical properties, several modifications have been reported for various mechanical properties of PMMA, including its flexural strength [14,30,33,68,134-136], impact strength [14,137-140], fracture toughness [141-143], and surface hardness $[67,98,141,144,145]$. The flexural strength (also known as the modulus of rupture or transverse strength) is assessed using a 3-point bending test according to the guidelines of ISO 20795-1 [81]. Ideally, the denture base should have a high flexural strength to bear the complex forces of mastication without permanent deformation or fracture [9]. A number of studies have investigated [14,30,33,68,134-136] flexural strength using various methods and types of PMMA. Barbrosa et al. [146] reported good flexural strength for heat-cured, cold-cured, and microwave-cured PMMA $(92.84 \pm 4.73,84.40 \pm 1.68$, and $109.63 \pm 5.31 \mathrm{MPa}$, respectively). The immersion of PMMA in water for a longer time decreased the flexural strength, resulting in increased water sorption [146]. In addition, the flexural strength of denture base PMMA can be affected by several factors, including the curing method, chemical composition, degree of polymerization, dimensions, and storage [9]. 
Although the flexural strength demonstrates a material's ability to withstand tensile, compressive, and shear stresses, the fracture toughness and impact strength of PMMA are also important for denture base applications. The fracture toughness describes a material's ability to resist crack propagation due to notches or defects present in the surface [147]. The fracture toughness of heat-cured PMMA $\left(2.06 \pm 0.17 \mathrm{MN} / \mathrm{m}^{3 / 2}\right)$ is significantly greater than cold-cured PMMA $\left(1.63 \pm 0.1 \mathrm{MN} / \mathrm{m}^{3 / 2}\right)$, regardless of the testing methodology [148]. Therefore, heat-cured PMMA performs better in inhibiting crack propagation and fracture. The impact strength describes the amount of impact energy required to cause a fracture $[78,147]$. High impact strength is desired to prevent the fracture of dentures when exposed to a high impact force, such as accidental dropping. The impact strength of a denture base can be remarkably reduced by the presence of tiny surface defects as a result of wear and tear. Even a micron-sized surface defect may act as a notch for crack propagation and fracture [149]. Certain additives, such as butadiene styrene, can significantly improve the impact strength [87], however they may affect other properties, such as the hardness and modulus of elasticity. The wear resistance of currently available PMMA materials is significantly lower compered to casting alloys and dental porcelains [150]. The wear resistance is directly related to the material's surface hardness, which is lower in case of PMMA compared to casting alloys and dental porcelains $[150,151]$. Therefore, further improvements in the mechanical properties of PMMA are desired, particularly the impact strength, flexural strength, hardness, and wear resistance.

\subsection{Chemical Properties of PMMA}

Ideally, the denture base materials should be highly insert and chemically non-reactive with oral fluids and nutrients. During function, the denture base materials are exposed to a variety of nutrients, which may drastically vary in terms multiple factors, including their chemical nature, $\mathrm{pH}$, and temperature [152]. Chemically, PMMA materials are organic resins that are negligibly soluble in water, however their solubility is high in organic solvents (such as ketones and esters). Similarly, alcoholic solutions act as plasticizers and may reduce the glass transition temperature. Therefore, storage or cleaning of dentures using alcoholic solutions should be avoided. Although PMMA does not chemically react with water, repetitive storage in water may result in dimensional changes or crazing due to cyclic water sorption and drying [153]. Cross-linking agents (such as ethylene glycol dimethacrylate and 1,4-butylene glycol dimethacrylate) are commonly added to PMMA. The cross-linking agents are beneficial by reducing the tendency of PMMA to solubilize in organic solvents [154] and enhance its resistance to crazing [155].

In addition, cross-linkers diminish the formation of oxygen inhibition layers and residual monomers in polymerized materials [154]. The currently available PMMA denture base materials have demonstrated satisfactory chemical stability in the oral cavity [77].

Based on the above discussion, it is evident that PMMA fulfills most of the requirements. including having good biocompatibility and physical and mechanical properties. The main concern remains the presence of residual monomers, which are released from the materials and jeopardize various properties, including the biocompatibility. Although heat-cured PMMA has demonstrated good mechanical strength and durability, fractured dentures are commonly reported in dental clinics, mainly due to poor impact strength, brittleness, and careless handling or accidental falls. Considering their good chemical stability and fracture toughness, PMMA dentures perform very well in the oral cavity for a reasonable period of time. The addition of various fibers and particles to PMMA may further reinforce its mechanical properties (Section 7). A number of shortcomings, such as the unfavourable thermal properties (low thermal conductivity or diffusivity, high coefficient of thermal expansion), brittleness, monomer leaching, and discoloration, still require improvement and further investigations. Overall, PMMA has the benefits of easy manipulation; cost-effectiveness; and good mechanical, physical, and aesthetic properties. Therefore, PMMA materials are commonly used for denture applications. 


\section{Applications of PMMA}

Polymeric acrylic materials are widely used for a range of applications in multiple fields, including engineering, healthcare, and dentistry (Figure 4). In addition to denture bases, other oral healthcare applications for PMMA include fabrication of artificial teeth, impression trays, temporary crowns, obturators for cleft palates, occlusal splints, printed or milled casts, dies for treatment planning, denture relining, and repair (Figure 4), which have been discussed.

a

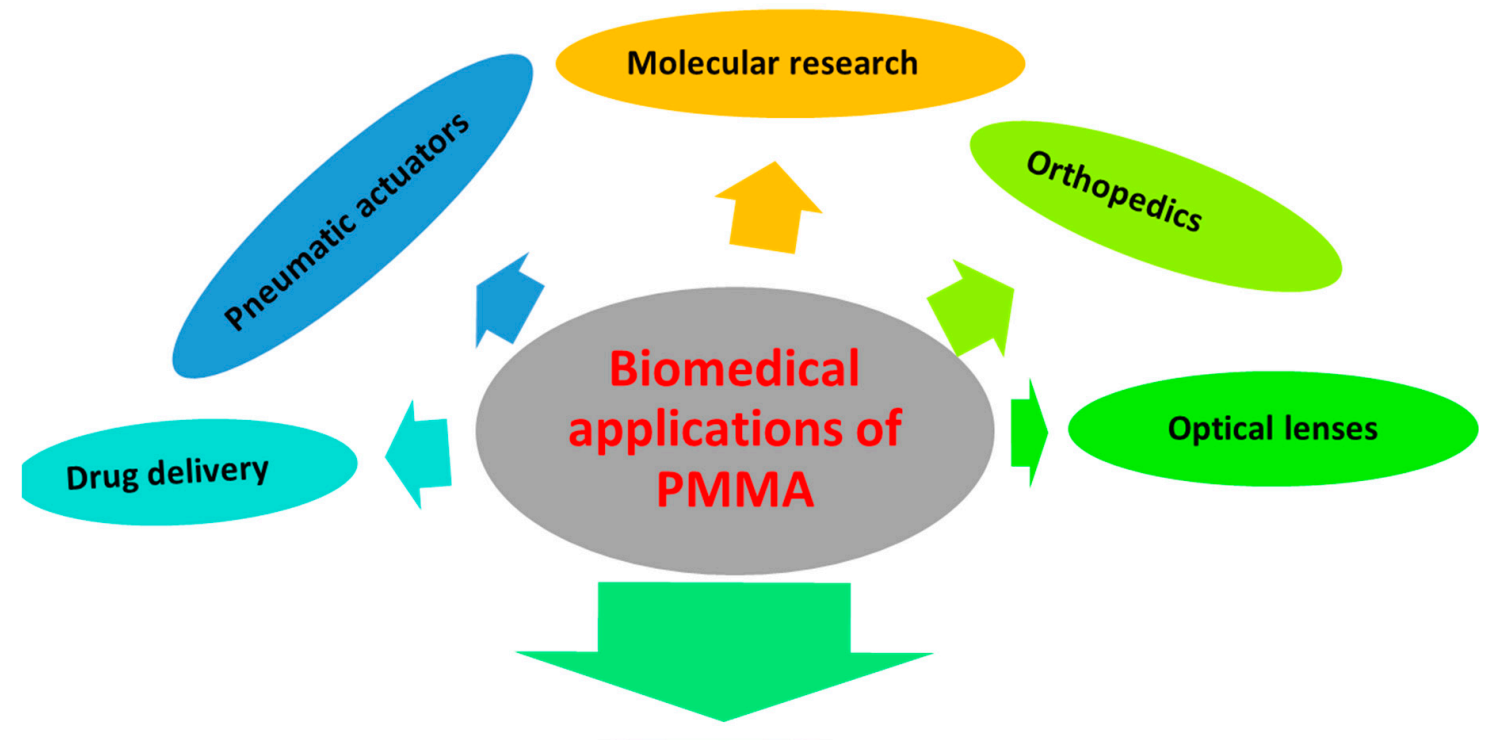

\section{Dental applications of PMMA}

b
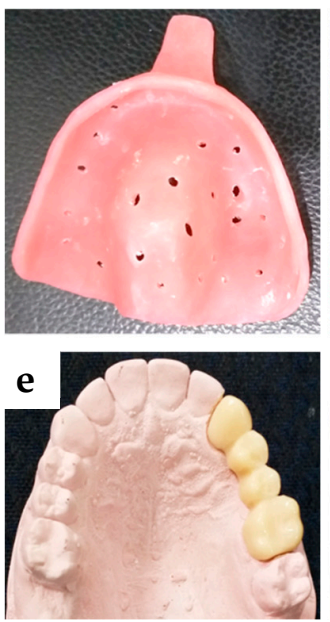

c

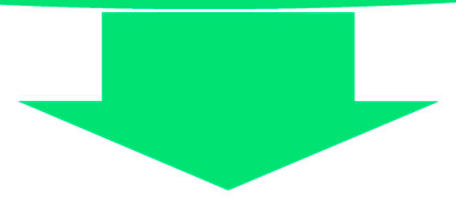

d
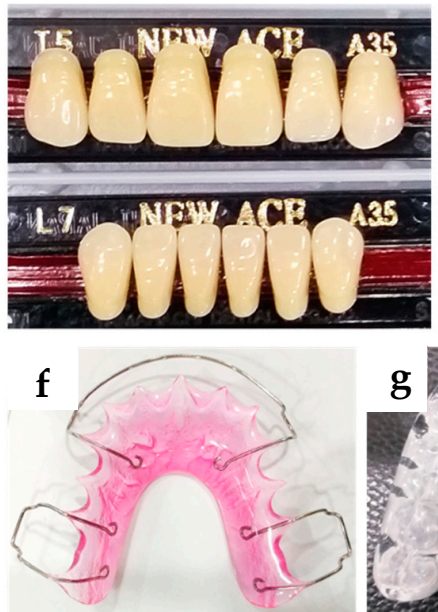

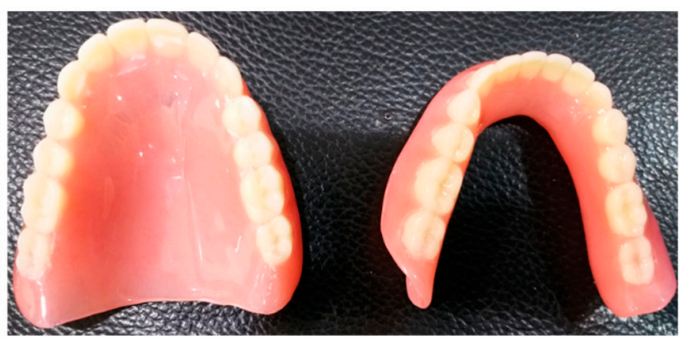

g

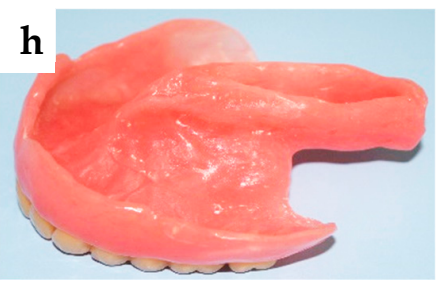

Figure 4. Key applications of PMMA: (a) in various biomedical disciplines; (b) secondary impression tray; (c) acrylic artificial teeth; (d) denture with acrylic teeth; (e) provisional fixed partial denture, crown; (f) orthodontic retainer; (g) occlusal splint; (h) palatal obturator replacing lost tissue following maxillectomy. 


\subsection{Denture Bases, Liners, and Reliners}

The alveolar bone is a dynamic tissue that undergoes continuous remodeling under physiological conditions [156,157]. The remodeling of alveolar bone alters the morphology of bone and denture bearing areas. A recent study reported a significantly greater resorption of the alveolar ridge in denture wearing patients compared to those who were edentulous but not wearing dentures [157]. The time-dependent alterations in the alveolar bone and the denture bearing tissues result in ill-fitting dentures, which then requiring relining to re-attain proper fit and stability. Accordingly, denture relining restores the vertical dimensions, retention, and stability of the old denture. Depending on the surface hardness, the lining materials are divided into hard liners such as PMMA [78,158]; and resilient liners. The resilient liners are elastic and composed of silicone elastomers [159-161], which act as shock absorber [161]. Both heat- and cold-cured PMMA materials are used for the relining of dentures (hard relining), using the old denture as an impression tray [10]. Heat-cured PMMA liners are usually supplied in the form of powder and liquid modified with the addition of plasticizers to reduce the glass transition temperature by to lubricating the polymer chains. Consequently, the PMMA material becomes comparatively flexible and resilient. The characteristic properties of PMMA liners are lost with time due to the leaching of plasticizers and increased stiffness. Cold-cured PMMA liners also can be used, which can allow chairside application without requiring laboratory work. However, due to their poor mechanical properties, leaching of monomers, and associated biocompatibility issues, their use is limited to temporary liners only. In contrast, heat-cured PMMA liners have demonstrated good bonding strength and wear resistance. However, the loss of plasticizers results in roughening of the surface, making the liners hard, and difficult to clean [10,162].

\subsection{Artificial Teeth}

Acrylic (PMMA) teeth are fabricated at an industrial scale using compression or injection molding techniques. Prefabricated teeth are supplied in a variety of tooth morphologies, sizes, and shades (Figure 4c). Once the artificial teeth have been matched to a patient's natural teeth (regarding the color, shape), they are contoured to fit the denture base through chemical bonding. Acrylic teeth have excellent biocompatibility, and good physical, mechanical, and aesthetic properties. In contrast to heat-cured PMMA, acrylic teeth have high resilience and flexibility, and therefore are less brittle and easier to polish. Compared with porcelain teeth, acrylic teeth are lightweight and do not cause clicking sounds or wear of the opposing teeth. In addition, acrylic teeth are dimensionally stable and have a coefficient of thermal expansion matching that of the denture base [10]. Although acrylic teeth bond chemically with the denture base, the poor bond strength and debonding remain the main concerns [163]. A significant proportion of broken dentures (22-30\%) involve debonding of acrylic teeth (mainly anterior teeth) due to having a smaller bonding surface area and the direction of functional stresses $[164,165]$. Various studies have investigated surface treatments in improving the adhesion of acrylic teeth. [166,167]. The application of methyl-methacrylate-based adhesives at the interface improves the bonding strength of acrylic teeth [167]. Similarly, the surface treatment of acrylic teeth surfaces by grinding and sandblasting increases the bond strength with the denture base [166]. The hardness, elastic modulus, and wear resistance of PMMA teeth are poor compared to the natural teeth or porcelain restorations, leading to rapid wear of PMMA teeth. Recently, silanized, feldspar-reinforced PMMA was compared with conventional acrylic teeth. The addition of silanized feldspar improved these properties (elastic modulus, hardness, and flexural strength) without compromising the impact strength. Similar results were reported by adding silica fillers, however the flexural strength was reduced [71].

\subsection{Temporary Crowns and Bridges}

The fabrication of ceramic or metal-ceramic crowns and fixed partial dentures involves time-consuming laboratory procedures [168,169], which may take several days to complete. 
Therefore, temporary restoration materials made from PMMA are commonly used to cover the prepared teeth until the fabrication of the ceramic restoration material is complete. PMMA temporary restoration materials can be prepared in significantly shorted periods of time, either chair-side using cold-cured PMMA or in the laboratory using heat-cured PMMA. Although PMMA is commonly used for temporary crowns and bridges, the rigidity and fracture toughness is not sufficient to withstand complex masticatory forces $[170,171]$. Because of the weak mechanical properties and abrasion resistance, the use of PMMA is restricted to temporary crowns and fixed bridges for a transitional period. As discussed earlier, heat-cured PMMA presents better properties compared to cold-cured PMMA. Furthermore, the polymerization of PMMA is an exothermic reaction that releases a magnificent amount of heat [50], which should be considered when using cold-cured PMMA in clinics. Although dentin is a good insulator of heat, the heat from the exothermic reaction may still reach and damage the underlying pulp, especially if the dentin thickness is less than $1 \mathrm{~mm}$. The thermal damage can be minimized using either an air-water spray as a coolant or a refrigerated putty matrix as a heat sink [172]. Alternatively, temporary crowns and fixed dentures for vital teeth can be fabricated via indirect approaches using heat-cured PMMA, which has better mechanical and physical properties. Cold-cured PMMA restoration materials contain uncured residual monomers $(3-5 \%)$ at significantly higher levels than heat-cured PMMA $(0.2-0.5 \%)$. The residual monomers may release into the oral environment and potentially irritate oral tissues [173]. For this application, one of the main disadvantages is the polymerization shrinkage, which equals 5-7\% volumetric shrinkage [174] linearly $(\sim 2 \%)$; this may lead to potential discrepancies in the fit of restoration materials, as well as microleakage. All such shortcomings should be considered while using PMMA for direct restorations in the oral cavity.

\subsection{Repair of Dentures}

Fractured dentures requiring repair are commonly reported in dental clinics [31,175]. The main reasons for denture fracture include the poor mechanical properties of PMMA [176] or accidental falls $[165,177]$. The repair of dentures is expensive and time-consuming [31]. In contrast, denture repair maintains the denture's dimensions and aesthetic characteristics [178,179]. Various types of PMMA materials are used for denture repair [31]. Although heat-cured PMMA has better mechanical properties $[175,180,181]$, the head curing procedure is time-consuming, with warpage of dentures due to reheating being the main concern [78,182]. Accordingly, cold-cured PMMA is favored for denture repair applications. Various modifications to PMMA materials can improve their strength for denture repair, with promising outcomes [31,68,141,142]. For example, the incorporation of $\mathrm{ZrO}_{2}$ nanoparticles improved the flexural strength of PMMA repair materials [29-31,142]. Previous studies have investigated light-cured PMMA for denture repair and reported several benefits, such as ease of manipulation, controlled polymerization time, no monomer issues, and better mechanical properties $[93,183,184]$. The repair strength of light-cured PMMA (40-44 MPa) is remarkably superior compared to heat-cured (21-34 MPa) and cold-cured ( 13MPa) PMMA materials [185]. In addition to the types of PMMA, various surface treatments, such as airborne abrasion using alumina particles, laser treatment [186], mechanical grinding with a bur [187], and immersion in a monomer solution [188-190] or organic solvents [191], may affect the repair strength of dentures.

\subsection{Obturators}

An obturator is a special prosthesis that is constructed to restore lost maxillary tissues (Figure $4 \mathrm{~h}$ ) and functional capabilities (mastication, deglutition, speech, aesthetics) following a maxillectomy [192-194]. Despite advancements being made in materials science, there are only a few material choices for the construction of obturators [195]. PMMA materials are the most commonly used materials for obturators [194-196]. To overcome polymerization shrinkage, the injection molding technique has been advocated due to it providing better marginal sealing and accuracy compared to conventional compression molding $[96,125]$. There are certain disadvantages of PMMA obturators, 
such as polymerization shrinkage, difficulty with undercuts due to the material's rigidity, or pressure sores on delicate tissues that have recently been exposed to the oral environment. Depending on the size of the defect, the PMMA obturators may become heavy. The weight can be reduced by using either a hollow design [197-199] or silicon core [200,201].

\subsection{Computer-Aided Design and Manufacturing (CAD/CAM) PMMA}

The $\mathrm{CAD} / \mathrm{CAM}$ technologies are used for the fabrication of various ceramic restorations, including inlays, onlays, crowns, and fixed partial dentures [202]. More recently, several researchers [203-211] investigated the use of CAD/CAM technologies for the fabrication of PMMA dental prostheses and compared the materials' properties and various aspects of the conventional and CAD/CAM PMMA materials. In contrast to the conventional "flask-pack-press" technique, CAD/CAM techniques commonly use rapid prototyping and milling techniques [208,210]. Although the chemistry of CAD/CAM PMMA is similar to that of conventional heat-cured PMMA, CAD/CAM PMMA shows superiority in terms of many properties, including its hardness, flexural strength, flexural modulus, and impact strength (Table 5). Both materials are equally biocompatible and without any significant differences in terms of monomer leaching [212]. The CAD/CAM PMMA mechanical properties and durability are improved compared to heat-cured PMMA (Table 5).

Table 5. Comparison of conventional heat-cured and CAD/CAM PMMA properties.

\begin{tabular}{|c|c|c|c|}
\hline Property & $\begin{array}{c}\text { Conventional Heat-Cured } \\
\text { PMMA }\end{array}$ & CAD/CAM PMMA & Reference \\
\hline Chemistry & \multicolumn{2}{|c|}{ Similar } & [208] \\
\hline Monomer leaching & \multicolumn{2}{|c|}{ No significant differences } & [212] \\
\hline Biocompatibility & \multicolumn{2}{|c|}{ Similar } & [208] \\
\hline Manipulation & \multirow[t]{6}{*}{ Flask-pack-press' } & $\begin{array}{l}\text { Rapid prototyping and } \\
\text { milling techniques }\end{array}$ & [208] \\
\hline $\begin{array}{c}\text { Candida albicans } \\
\text { adherence/stomatitis }\end{array}$ & & Reduced & [207] \\
\hline Mechanical properties & & Improved & {$[204,208]$} \\
\hline Hardness & & Increased & [206] \\
\hline Flexural strength & & Improved & [203-205] \\
\hline $\begin{array}{l}\text { Flexural modulus and impact } \\
\text { strength }\end{array}$ & & Improved & [204] \\
\hline Durability & \multirow{7}{*}{ Higher; reduced with aging } & Improved & [204] \\
\hline Teeth bond strength & & Lower; less effect with aging & [209] \\
\hline Hydrophobicity & & Higher & [205-207] \\
\hline Contact angle & & & [205] \\
\hline \multirow{3}{*}{ Surface roughness } & & & [205] \\
\hline & & Lower & [207] \\
\hline & & $\begin{array}{c}\mathrm{Ra}=0.2 \mu \mathrm{m}, \text { which is below } \\
\text { the threshold for plaque } \\
\text { accumulation }\end{array}$ & [123] \\
\hline
\end{tabular}

Interestingly, the adherence of fungal Candida albicans was remarkably reduced in CAD/CAM dentures [207], resulting in enhanced hydrophobicity and surface properties [205-207]. The increased hydrophobicity inhibits plaque accumulation on the polymer surface [213,214]. Therefore, due to the inhibition of Candida albicans attachment, CAD/CAM PMMA dentures may benefit patients prone to denture stomatitis [215-219]. Due to their superior mechanical properties, CAD/CAM PMMA fixed partial dentures (up to 4 units) can be used where long term (up to one year) temporization is needed in certain clinical situations [220]. 


\subsection{Miscellaneous Applications}

In addition to the above discussed applications, PMMA-based materials are frequently used in additional applications in various disciplines of clinical dentistry. In orthodontics, various removeable orthodontic appliances [221-224], such as retainers, bite planes, myofunctional appliances, bite guards, and occlusal splints, are fabricated using PMMA. The material characteristics and the fabrication process for orthodontic appliances are similar to PMMA denture bases, as described earlier; the only differences are their design and functional capacities, which depend on the application. In addition, PMMA base adhesives are used to bond orthodontic brackets [225]. In addition, PMMA is conveniently used to make secondary impression trays, modify primary trays, and copy (duplicate) dentures [162,226]. Due to its cheap cost and ease of manipulation, PMMA is frequently used to embed or fix specimens for restorative dentistry research $[227,228]$ and for fabrication of study casts for treatment planning. Further modifications and improvements to the properties of PMMA are likely to overcome the major shortcomings of this most commonly used dentistry polymer and are likely to remarkably enhance its applications in various disciplines of clinical dentistry.

\section{Modifications of PMMA}

Despite there being plenty of research on and understanding of biomaterials, there is a lack of ideal biomaterials for dental applications [229]. Although PMMA certainly has many good properties (such as its strength, easy manipulation, cost-effectiveness) and has gained popularity for several dental applications, as discussed above, there are several shortcomings of this material that fall short of an ideal material's properties for denture bases or other dental applications. For example, polymerization shrinkage (linear and volumetric) may result in remarkable dimensional changes and inaccuracies during denture fabrication [78]. Similarly, the presence of residual monomers always remains an issue affecting the properties and biocompatibility $[58,115,230]$. Other properties of PMMA that require improvement include its poor fatigue strength, low impact strength, weak bonding strength, low thermal conductivity, susceptibility to crazing, high thermal expansion coefficient, poor color stability, susceptibility to warpage, and porosity [231]. Each drawback has its own consequences, such as the poor flexural and impact strength resulting in fatigue failure or accidental fracture of dentures $[140,165,178]$. Various representative examples of PMMA modification and associated outcomes are shown in Figure 5. Therefore, the improvement of PMMA properties is required and remain a focus for researchers. In recent years, a wide range of modifications of PMMA-based materials (such as reinforcement of fibers or filler particles, antimicrobial modifications) have been investigated to improve their performance $[30,31,51-53,68,143,232]$, which have been discussed.

\subsection{Mechanical Reinforcement Using Fibers}

To improve the properties of PMMA materials, a variety of fibers have been added and extensively characterized (Table 6). Several studies [13-22] have reported the improvement of various properties of fiber-reinforced PMMA. The characteristic reinforcement benefits are obtained due to the greater length of the fibers compared to the cross-sectional diameter. In addition, the enhancement of mechanical properties is affected by fibers' morphology (length, diameter), orientation in the matrix, concentration, pre-impregnation, and silane treatment [233]. For example, the fibers can be either continuous and long, running through the span of the prosthesis [234], or can be short. Adding fibers shorter than the critical length $(0.5-1.6 \mathrm{~mm}$ for glass fibers) may negatively affect the mechanical properties [235]. Similarly, the orientation of the fibers is also important in defining their mechanical properties [235-237]. The unidirectional orientation of fibers results in anisotropy and reinforced strength in one direction [238], while a multidirectional or woven orientation results in isotropic dispersion of fibers and reinforced strength in all directions [239]. 

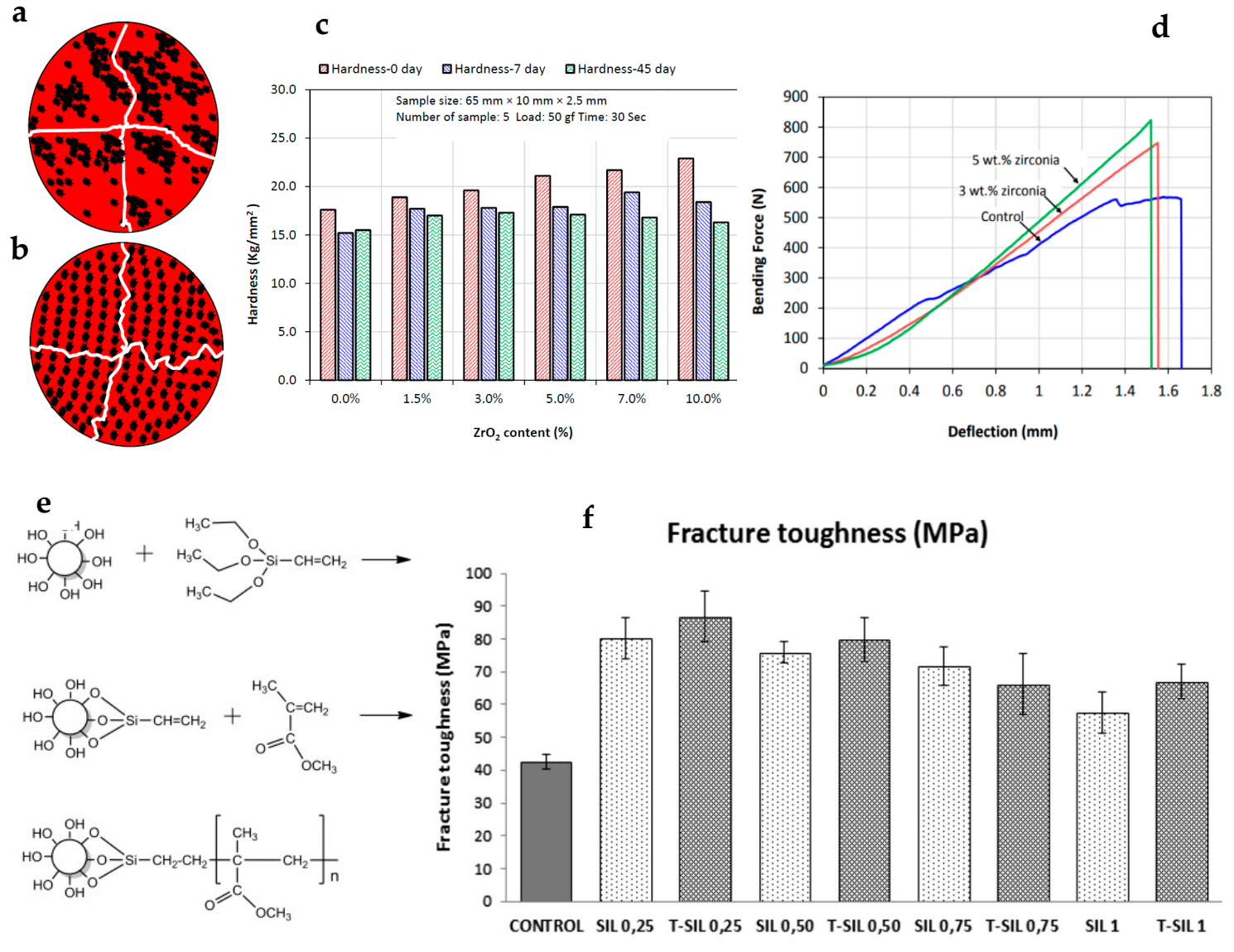

f Fracture toughness (MPa)

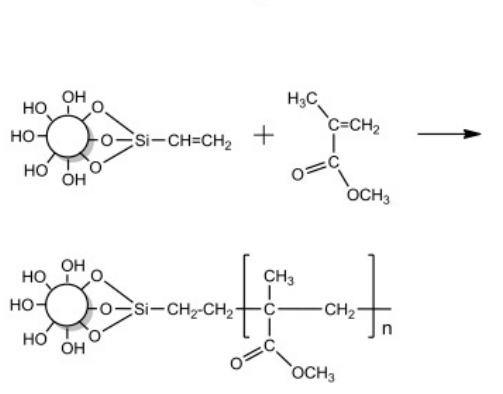

g

h

I

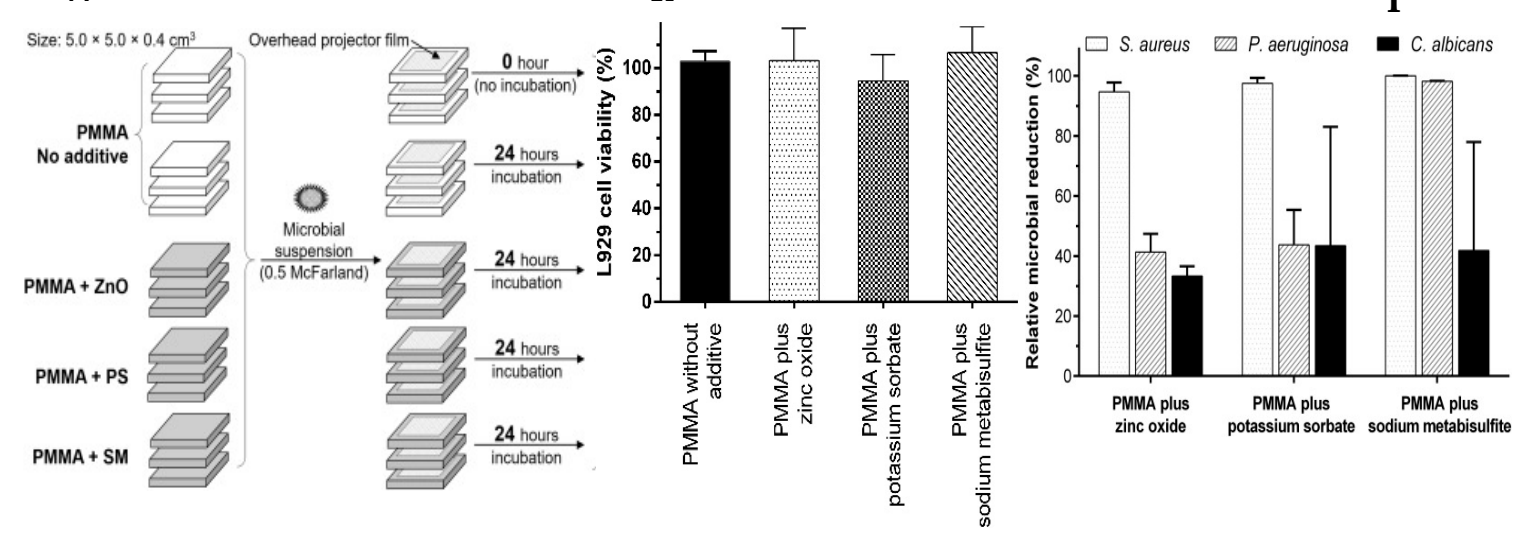

Figure 5. Various representative examples of PMMA modifications and associated outcomes: (a) randomly distributed filler particles allowing crack propagation; (b) uniformly dispersed particles that enhance fracture toughness through crack diversion [66]; (c) impregnation with $\mathrm{ZrO}_{2}$ resulted in increased Vickers hardness values [51] and (d) flexural properties [30]; (e) silica nanoparticle surface modification using trietoxyvinylsilane and chemical bonding to MMA to enhance the fracture toughness (f) of modified PMMA (from [240] with permission), PMMA (control), PMMA reinforced with silica $\left(\mathrm{SiO}_{2}\right)$ nanoparticles measuring $\sim 12 \mathrm{~nm}$ (PMMA-SIL), and PMMA containing trietoxyvinylsilane-modified $\mathrm{SiO}_{2}$ nanoparticles (PMMA T-SIL); (g) antimicrobial functionalization of PMMA by adding zinc oxide, potassium sorbate (PS), and sodium metabisulfite (SM) (from [241] with permission) showed no remarkable effects on L929 cell viability (h), however resulted in a significant antimicrobial action against bacteria and Candida albicans (I). 
Table 6. Characteristics of various fibers used for the mechanical reinforcement of PMMA.

\begin{tabular}{|c|c|c|}
\hline Fiber type & Characteristic Description and Main Outcomes & Reference \\
\hline Carbon & $\begin{array}{c}\text { Enhancement of the mechanical properties, including tensile strength, } \\
\text { flexibility, fracture resistance, and elastic modulus. } \\
\text { Reduced thermal expansion of modified PMMA materials. } \\
\text { Poor aesthetic properties due to the color of fibers. }\end{array}$ & $\begin{array}{c}{[20,242]} \\
{[20]}\end{array}$ \\
\hline Aramid (Kevlar) & $\begin{array}{l}\text { Polyamide fibers that have better wettability (coupling pre-treatment is } \\
\text { not required) and improved mechanical properties, such as fracture } \\
\text { resistance. } \\
\text { Poor aesthetics due to yellowish color; fibers exposed to the surface are } \\
\text { irritable to patient's tissues. Difficult to finish and polish the surface. } \\
\text { Increasing the concentration of fibers reduced the hardness. }\end{array}$ & $\begin{array}{c}{[18,75,244]} \\
{[18,75]}\end{array}$ \\
\hline Nylon & $\begin{array}{l}\text { Adding nylon fibers improved the flexural strength. } \\
\text { Improved structural elasticity and fracture resistance. }\end{array}$ & $\begin{array}{l}{[245]} \\
{[103]}\end{array}$ \\
\hline $\begin{array}{l}\text { Polyethene and } \\
\text { polypropylene }\end{array}$ & $\begin{array}{l}\text { Adding surface-treated fibers improved the impact strength. } \\
\text { Superior toughness and ductility. } \\
\text { In addition to impact strength, adding silanized fibers improved the } \\
\text { tensile and transverse strengths of heat-cured PMMA, however wear } \\
\text { resistance was poor. }\end{array}$ & $\begin{array}{c}{[21,139]} \\
{[22,246,247]} \\
{[17]}\end{array}$ \\
\hline \multirow[b]{2}{*}{ Glass } & $\begin{array}{l}\text { The aesthetic properties were not affected due to their white color. } \\
\text { Technique was sensitive and required surface treatment, therefore is not } \\
\text { used extensively. }\end{array}$ & $\begin{array}{c}{[21,243]} \\
{[243]}\end{array}$ \\
\hline & $\begin{array}{l}\text { Glass fibers can be used in various forms (woven, loose); provide } \\
\text { excellent reinforcement and aesthetics compared to other fibers. } \\
\text { A remarkable increase in the denture base toughness, Vickers hardness, } \\
\text { impact strength, and flexural strength was observed. } \\
\text { A remarkable reduction in the deformation }(<1 \%) \text {. } \\
\text { The silanized glass fibers enhanced the flexural strength, while the } \\
\text { strength of modified PMMA may be influenced by the proportion and } \\
\text { positioning of fibers. }\end{array}$ & $\begin{array}{l}{[15,16,248,249]} \\
{[15]} \\
{[19]}\end{array}$ \\
\hline
\end{tabular}

In addition to the fiber morphology and orientation, the fiber-matrix interface contributes greatly to the mechanical reinforcement. The pre-impregnation of fibers using monomers has been demonstrated to enhance the fibers' properties by improving their wettability and adhesion within the matrix $[250,251]$. In addition, pre-impregnated fibers reduce voids in the matrix and facilitate uniform distribution of stresses [9]. Similarly, treating fibers with silane coupling agents encourages bonding between fibers and the matrix [244]. The silanated fibers demonstrated improved bonding strength compared to the untreated fibers $[252,253]$. However, the cost of commercially available fibers and further pre-treatment processing increase the overall cost of denture production.

\subsection{Mechanical Reinforcement Using Particles}

To reinforce the properties of PMMA materials, a variety of filler particles have been investigated, including ceramics and metals (Table 7). It is obvious from these studies that the addition of particles resulted in no biocompatibility issues and improved various properties of the PMMA, including the mechanical properties [23-37], thermal conductivity [23,24,31,254,255], dimensional stability [256], and antimicrobial activity [257-266], and also reduced the solubility and water sorption [267,268]. The beneficial outcomes resulting from the use of nanoparticles are achieved due to their characteristic features, such as their high surface area and better distribution [34,269].

In addition, the properties of nanoparticles (morphology, loading, type) affect the final properties of reinforced PMMA [34]. For example, The $\mathrm{ZrO}_{2}$ nanotubes demonstrated superior reinforcement of the mechanical properties compared to the $\mathrm{ZrO}_{2}$ particles [270]. Similarly, adding metallic nanoparticles enhances the thermal conductivity of the denture base and allows better judgement of food temperature [104,271]. In addition, hybrid reinforcement has been carried out using various fibers [21], 
particles [76,126,131,272], and combinations of fibers and particles [273]. Hybrid reinforcement improves the interface and enhance the loading capacity, improving the material's properties [274]. Hybrid reinforcement using different types of fibers improve various properties of PMMA, including the tensile strength, flexural modulus [275], surface roughness [272], radiopacity, and thermal conductivity [276], and also results in decreased polymerization shrinkage [76,126]. Although the use of various combinations of hybrid reinforcements resulted in promising outcomes, additional research is required to explore various other materials and combinations to further improve the properties of PMMA materials.

Table 7. Characteristics of various filler particles used for the mechanical reinforcement of PMMA.

\begin{tabular}{|c|c|c|}
\hline Particles & Modification and Outcome & Reference \\
\hline \multirow{7}{*}{ Alumina $\left(\mathrm{Al}_{2} \mathrm{O}_{3}\right)$} & $\begin{array}{l}\text { Addition of alumina } \mathrm{Al}_{2} \mathrm{O}_{3} \text { nanoparticles to PMMA powder resulted in } \\
\text { good biocompatibility. }\end{array}$ & [277] \\
\hline & Silane-treated aluminium particles remarkably improved the & \\
\hline & mechanical properties-mainly the compressive and flexural strengths, & {$[25,26]$} \\
\hline & as well as the wear resistance. & \\
\hline & $\begin{array}{c}\text { No significant effects on the water sorption or surface roughness of } \\
\text { PMMA. }\end{array}$ & {$[145]$} \\
\hline & Significantly improves the thermal conductivity of PMMA. & [255] \\
\hline & $\begin{array}{l}\text { The main limitation of the } \mathrm{Al}_{2} \mathrm{O}_{3} \text { reinforcement is that it causes } \\
\text { discoloration of the resin. }\end{array}$ & [25] \\
\hline \multirow{5}{*}{ Zirconia $\left(\mathrm{ZrO}_{2}\right)$} & $\begin{array}{l}\text { Significant improvement in mechanical properties, including fracture } \\
\text { toughness, compressive and fatigue strengths. }\end{array}$ & [29-32] \\
\hline & $\begin{array}{c}\text { Using silane coupling agent (3.5\%) improved the PMMA- } \mathrm{ZrO}_{2} \\
\text { interface and flexural strength. }\end{array}$ & [278] \\
\hline & $\begin{array}{c}\mathrm{ZrO}_{2} \text { nanoparticles (NPs) added to the PMMA improved the thermal } \\
\text { conductivity. }\end{array}$ & [31] \\
\hline & $\begin{array}{c}\text { The } \mathrm{ZrO}_{2} \text { nanotubes demonstrated superior reinforcing effects } \\
\text { compared to } \mathrm{ZrO}_{2} \text { particles. }\end{array}$ & [270] \\
\hline & Increased the water sorption, however it remained within the limits. & [279] \\
\hline \multirow{5}{*}{ Titania $\left(\mathrm{TiO}_{2}\right)$} & $\begin{array}{c}\text { Adding } \mathrm{TiO}_{2} \text { particles enhanced the thermal conductivity, fracture } \\
\text { toughness, and hardness. }\end{array}$ & {$[254]$} \\
\hline & Increase in the impact strength. & [280] \\
\hline & $\begin{array}{c}\text { The addition of silanized } \mathrm{TiO}_{2} \text { particles showed similar effects by } \\
\text { improving the surface hardness, transverse and impact strengths. } \\
\text { The water sorption and solubility were also reduced. }\end{array}$ & [267] \\
\hline & $\begin{array}{l}\text { The fluorapatite or apatite-coated } \mathrm{TiO}_{2} \text { demonstrated antifungal effects } \\
\text { and inhibited Candida growth. }\end{array}$ & {$[262,263]$} \\
\hline & $\begin{array}{l}\text { Due to poor wettability, there is a need for titanium coupling agent } \\
\text { reinforcement in PMMA. The modification of PMMA by the } \\
\text { incorporation of barium titanate (radiopacifier) reduced the fracture } \\
\text { toughness. }\end{array}$ & [281] \\
\hline \multirow{4}{*}{ Silver } & $\begin{array}{l}\text { Due to their metallic nature, adding silver particles improved the } \\
\text { compressive strength and thermal conductivity of PMMA. }\end{array}$ & {$[23,24]$} \\
\hline & $\begin{array}{c}\text { Due to their antimicrobial properties, silver particles inhibit bacterial } \\
\text { attachment. Dentures containing siliver nanoparticles have shown } \\
\text { antifungal activity. }\end{array}$ & {$[257-261]$} \\
\hline & $\begin{array}{l}\text { The addition of silver and graphene nanoparticles to PMMA } \\
\text { significantly enhanced the mechanical properties (tensile, compressive, } \\
\text { and flexural strengths) and lowered the water absorption. }\end{array}$ & [268] \\
\hline & No significant changes in the flexural strength of PMMA. & [255] \\
\hline
\end{tabular}


Table 7. Cont.

\begin{tabular}{|c|c|c|}
\hline Particles & Modification and Outcome & Reference \\
\hline \multirow{4}{*}{$\begin{array}{l}\text { Nanodiamond } \\
\text { (ND) }\end{array}$} & The ND particles are bioactive and reinforce acrylic polymers. & {$[54,282]$} \\
\hline & $\begin{array}{l}\text { Adding ND nanoclusters }(20 \mathrm{~nm} ; \sim 0.83 \mathrm{wt} \%) \text { to PMMA significantly } \\
\text { improved the elastic modulus }(\sim 2.084 \mathrm{GPa}) \text { and impact strength. }\end{array}$ & {$[282]$} \\
\hline & $\begin{array}{l}\text { Adding only } 0.1 \mathrm{wt} . \% \text { ND to PMMA remarkably increased the flexural } \\
\text { strength, in addition to inhibiting the growth of Candida albicans fungal } \\
\text { infection and salivary biofilm. }\end{array}$ & [283] \\
\hline & $\begin{array}{l}\text { Diminished Candida albicans attachment corresponding to the reduced } \\
\text { surface roughness, therefore may benefit in the prevention of denture } \\
\text { stomatitis. }\end{array}$ & [284] \\
\hline \multirow[t]{2}{*}{$\begin{array}{l}\text { Hydroxyapatite } \\
\text { (HA) }\end{array}$} & $\begin{array}{l}\text { Inorganic HA improved the PMMA properties, including the elastic } \\
\text { modulus and flexural strength. }\end{array}$ & {$[27,28]$} \\
\hline & $\begin{array}{l}\text { The } \mathrm{SiO}_{2} \text { nanoparticles improved the mechanical properties of PMMA. } \\
\text { The PMMA modified by mica showed improved surface hardness, } \\
\text { dimensional stability, and thermal properties. However, the flexural } \\
\text { strength was compromised due to the weakening of mica bonding with } \\
\text { the acrylic resin. }\end{array}$ & [33-36] \\
\hline \multirow{3}{*}{$\begin{array}{l}\text { Silica }\left(\mathrm{SiO}_{2}\right) \\
\text { based particles }\end{array}$} & $\begin{array}{c}\text { The fluoride glass fillers containing PMMA inhibited the microbial } \\
\text { adhesion but enhanced the surface roughness. }\end{array}$ & {$[264,265]$} \\
\hline & $\begin{array}{c}\text { The incorporation of mesoporous silica nanoparticles loaded with an } \\
\text { antifungal drug (amphotericin B) resulted in long-term antifungal } \\
\text { activity against Candida albicans. }\end{array}$ & [266] \\
\hline & $\begin{array}{l}\text { Increasing the concentration of nanosilica may lead to biocompatibility } \\
\text { issues; however, at lower concentrations (less than 2\%) there is no } \\
\text { cytotoxicity. }\end{array}$ & [35] \\
\hline
\end{tabular}

In addition to several fibers and particles (Tables 6 and 7), carbon nanotubes (CNTs) have been investigated to reinforce the properties of PMMA [38-42]. The rationale for using CNTs is their exceptional electrical and mechanical properties, the fact that they are many times stronger than steel [285], and their low density and resilience [38]. There are two distinct structurally stable types of CNTs [38]: single-walled (single seamlessly wrapped cylindrical tube) and multiwalled (array of concentric nanotubes nested concentrically) CNTs.

Wang et al. [38] added variable concentrations of multiwalled CNTs carbon to PMMA and characterized the various mechanical properties. Although adding CNTs in amounts of up to $1 \%$ improved the flexural strength and resilience, increasing the CNT concentration ( $2 \%)$ compromised the properties due to the insufficient dispersion of CNTs [38,42]. A similar study reported the enhancement of all tested mechanical properties form the addition of $1 \%$ of CNTs [40]. Qasim et al. added single-walled NCTs to various light-cured PMMA materials and observed no significant improvements in the flexural properties [39]. In addition to the mechanical properties, CNT loading also reduced the polymerization shrinkage remarkably [41], which is very beneficial for improving the dimensional accuracy of prostheses, particularly crowns and fixed partial dentures. Although the addition of CNTs resulted in the establishment of good interfaces, the main concern is the bad color $[40,286]$, which limits the use of PMMA-CNT materials to non-aesthetic areas.

\subsection{Chemical Modification of PMMA}

The properties of PMMA materials can be improved through chemical modification. A typical example of chemical modification is the incorporation of rubber to form a PMMA-rubber semi-interpenetrating network, which improves the impact strength [75]. Crack propagation through the PMMA matrix is decelerated when the crack line reaches the rubber interface. Accordingly, the denture can withstand higher impact stresses before fracturing, ultimately improving the fatigue resistance. Due to the elastic nature of rubber, the denture gains more flexibility from having a reduced elastic modulus [287]. Furthermore, the properties of rubber-PMMA materials vary vastly depending 
on the concentration of rubber (styrene-butadiene copolymer) added to the PMMA. One study showed that the Young's modulus and tensile strength values were reduced by increasing the rubber content [43]. Considering its high impact strength and fracture resistance, rubber-incorporated PMMA can be beneficial for patients who are prone to dropping their prosthesis repeatedly, such as senile and Parkinson's disease patients [287]. The drawback of these materials is their high cost [75]. Currently, very little research is available regarding the chemical modification of PMMA. Therefore, further research exploring chemical modifications of PMMA using various materials is required, including cross-linkers, resins, and copolymers.

\subsection{Antimicrobial Functionalization of PMMA}

Biofilm formation and bacterial growth are always concerning due to the associated infectious diseases and financial burden on the healthcare system [288]. In the oral cavity, bacterial adhesion and plaque is associated with various prevalent conditions, including dental caries (tooth decay), periodontal diseases, and denture-induced stomatitis resulting in fungal growth [289]. Therefore, the development and functionalization of biomaterials with antimicrobial properties is always desired [288]. To impart antimicrobial properties on the materials, various modifications have been reported, such as the addition of antimicrobial polymers, inorganic nanoparticles, or medicaments, as well as surface functionalization, demonstrating promising outcomes against various oral microorganisms [290]. Several studies have reported the inhibition of microbial adhesion and growth on PMMA surfaces containing fluoride glass fillers [264,265], fluorapatite, or apatite-coated $\mathrm{TiO}_{2}$ [262,263]. The availability of fluoride in the oral cavity results in the enhancement of antibacterial activity against the oral microbiomes [291]. Similarly, the growth of denture-stomatitis-associated Candida albicans was remarkably inhibited by the addition of silver nanoparticles [257-261], nanodiamonds [283], and mesoporous silica nanoparticles loaded with the antifungal medicament amphotericin B [266]. The addition of thymoquinone antifungal agent (up to 1\%) to the PMMA had no effect on the surface and flexural properties [292]. Quaternary ammonium compounds are also known for their antibacterial activity and have been reviewed comprehensively for the modification of various dental materials [293]. Although quaternary ammonium-based compounds showed good antimicrobial activity when added to restorative dental materials [294,295], they may affect the properties of other materials, such as the polymerization shrinkage, flexural strength, modulus, and biocompatibility, if used in higher concentrations [293]. Adding quaternary ammonium compounds $(2 \%)$ to cured PMMA resulted in antibacterial and antifungal activity in vitro. Dentures containing quaternary ammonium compounds may benefit geriatric patients prone to developing denture stomatitis [296,297].

Surface functionalization is another approach that can produce antimicrobial properties and inhibition of the bacterial adhesion on a material's surface [288]. The surface functionalization engineers the material's surface, therefore making it less likely to affect the bulk properties. Recently, Mai et al. [298] reported on the surface functionalization of PMMA using oxygen plasma and thermal treatment. Chlorhexidine was incorporated to induce the antimicrobial activity via controlled and sustained drug release from the functionalized surface. In addition, no cellular toxicity or apoptotic cell death was observed during the cytotoxicity evaluation [298]. Lee et al. [299] incorporated graphene oxide nanosheets into PMMA and characterized for their physical and antimicrobial properties. The addition of graphene oxide nanosheets and non-thermal oxygen plasma surface treatment improved the hydrophilicity and surface antiadhesive effects [299]. Recently, various food preservatives (such as sodium metabisulfite, potassium sorbate) have been added to PMMA. The modified PMMA materials demonstrated acceptable flexural properties and enhanced antimicrobial activity without showing any cytotoxicity [241]. Although the addition of the food preservatives altered the mechanical properties, the materials still provided acceptable flexural properties.

Although the addition of antimicrobial nanoparticles has not resulted in biocompatibility issues, the majority of research has been conducted in vitro [290]. A material's responses, including its antimicrobial activity, may be different when in a complex dynamic oral environment. Various antimicrobial additives 
may lead to cytotoxicity. Therefore, further in vivo clinical studies are essential to validate the efficacy of the antimicrobial agents and establish their biosafety and biocompatibility [290].

\section{Conclusions and Future Trends}

The present article comprehensively reviewed the properties, dental applications, and recent modifications of PMMA-based materials. According to ADA Specification No. 12, the majority of PMMA properties satisfactorily fulfil the requirements for denture base polymers. Nevertheless, the discoloration, hydrolytic degradation, and fracture of PMMA appliances are commonly reported in dental clinics, indicating that the properties of PMMA require further improvement. In the recent decades, plentiful research has been conducted, focusing om further improving the physical and mechanical properties of PMMA. Modifications of PMMA involving chemical or mechanical reinforcement using supplementary materials (fibers, nanofillers, nanotubes and hybrid materials) have resulted in remarkable improvements in the mechanical (impact strength, cyclic fatigue, flexural strength, and wear resistance), physical (thermal conductivity, water sorption, solubility, and dimensional stability), and biological (antimicrobial activity, biocompatibility) properties (Section 7). However, it remains challenging to improve one set of properties without compromising the rest of the properties. For example, although adding nanoparticles or fibers can improve the strength of PMMA, this may compromise the aesthetics (color, translucency) or increase the biocompatibility issues via the leaching of degradation products in the oral cavity. Although the current modifications of PMMA have resulted in encouraging outcomes, there is a long way to in using modified PMMA materials in dental clinics for practical applications. The biocompatibility and in vivo performance of modified materials are still questionable and require further investigation. Further research should focus on understanding the interactions of modified materials at the molecular levels, the evaluation of various properties following ADA specifications, and clinical performance in either simulated oral environments or in vivo clinical studies.

Funding: This research received no external funding.

Acknowledgments: The author would like to thank Fazal Khan for assisting in the manipulation of PMMA (Figure 2), Waqas Tanveer (provided the obturator image; Figure 4h), and Syed Rashid Habib for proofreading the manuscript.

Conflicts of Interest: The authors declare no conflict of interest.

\section{References}

1. Rokaya, D.; Srimaneepong, V.; Sapkota, J.; Qin, J.; Siraleartmukul, K.; Siriwongrungson, V. Polymeric materials and films in dentistry: An overview. J. Adv. Res. 2018, 14, 25-34. [CrossRef] [PubMed]

2. $\mathrm{Xu}, \mathrm{X} . ; \mathrm{He}$, L.; Zhu, B.; Li, J.; Li, J. Advances in polymeric materials for dental applications. Polym. Chem. 2017, 8, 807-823. [CrossRef]

3. Imazato, S.; Ma, S.; Chen, J.; Xu, H.H.K. Therapeutic polymers for dental adhesives: Loading resins with bio-active components. Dent. Mater. 2014, 30, 97-104. [CrossRef] [PubMed]

4. Najeeb, S.; Zafar, M.S.; Khurshid, Z.; Siddiqui, F. Applications of polyetheretherketone (PEEK) in oral implantology and prosthodontics. J. Prosthodont. Res. 2016, 60, 12-19. [CrossRef]

5. Kwon, J.; Kim, Y.H.; Choi, E.H.; Kim, K. Development of ultra-hydrophilic and non-cytotoxic dental vinyl polysiloxane impression materials using a non-thermal atmospheric-pressure plasma jet. J. Phys. D 2013, 46, 195201. [CrossRef]

6. Ohkawa, K.; Hayashi, S.; Kameyama, N.; Yamamoto, H.; Yamaguchi, M.; Kimoto, S.; Kurata, S.; Shinji, H. Synthesis of collagen-like sequential polypeptides containing O-phospho-L-hydroxyproline and preparation of electrospun composite fibers for possible dental application. Macromol. Biosci. 2009, 9, 79-92. [CrossRef]

7. Deb, S. Polymers in dentistry. J. Eng. Med. 1998, 212, 453-464. [CrossRef]

8. Alqurashi, H.; Khurshid, Z.; Azeem Ul Yaqin, S.; Rashid Habib, S.; Rokaya, D.; Sohail Zafar, M. Polyetherketoneketone (PEKK): An emerging biomaterial for oral implants and dental prostheses. J. Adv. Res. 2020, in press. [CrossRef] 
9. Hassan, M.; Asghar, M.; Din, S.U.; Zafar, M.S. Chapter 8. In Thermoset Polymethacrylate-Based Materials for Dental Applications; Elsevier: Amsterdam, The Netherlands, 2019; pp. 273-308.

10. Nejatian, T.; Pezeshki, S.; Yaqin Syed, A.U. Acrylic denture base materials. In 5 Advanced Dental Biomaterials; Khurshid, Z., Najeeb, S., Zafar, M.S., Sefat, F., Eds.; Woodhead Publishing: Cambridge, UK, 2019; pp. $79-104$.

11. Sakaguchi, R.L.; Powers, J.M. Craig's Restorative Dental Materials; Elsevier/Mosby: Philadelphia, PA, USA, 2012.

12. Zafar, M.S.; Ahmed, N. Nano-mechanical evaluation of dental hard tissues using indentation technique. World Appl. Sci. J. 2013, 28, 1393-1399.

13. Chang, M.; Hung, C.; Chen, W.; Tseng, S.; Chen, Y.; Wang, J. Effects of pontic span and fiber reinforcement on fracture strength of multi-unit provisional fixed partial dentures. J. Dent. Sci. 2019, 14, 309-317. [CrossRef]

14. Al-Thobity, A.M. The impact of polymerization technique and glass-fiber reinforcement on the flexural properties of denture base resin material. Eur. J. Dent. 2020, 14, 92-99. [CrossRef] [PubMed]

15. Moreno-Maldonado, V.; Acosta-Torres, L.; Barceló-Santana, F.; Vanegas-Lancón, R.; Plata-Rodríguez, M.; Castano, V. Fiber-reinforced nanopigmented poly (methyl methacrylate) as improved denture base. J. Appl. Polym. Sci. 2012, 126, 289-296. [CrossRef]

16. Hamouda, I.M.; Beyari, M.M. Addition of glass fibers and titanium dioxide nanoparticles to the acrylic resin denture base material: Comparative study with the conventional and high impact types. Oral Health Dent. Manag. 2014, 13, 107-112. [PubMed]

17. Ismaeel, I.J.; Alalwan, H.K.; Mustafa, M. The effect of the addition of silanated poly propylene fiber to polymethylmethacrylate denture base material on some of its mechanical properties. J. Baghdad Coll. Dent. 2015, 27, 40-47. [CrossRef]

18. Chen, S.; Liang, W.; Yen, P. Reinforcement of acrylic denture base resin by incorporation of various fibers. J. Biomed. Mater. 2001, 58, 203-208. [CrossRef]

19. Vallittu, P.K.; Lassila, V.P.; Lappalainen, R. Acrylic resin-fiber composite-Part I: The effect of fiber concentration on fracture resistance. J. Prosthet. Dent. 1994, 71, 607-612. [CrossRef]

20. Manley, T.R.; Bowman, A.J.; Cook, M. Denture bases reinforced with carbon fibres. Br. Dent. J. 1979, $146,25$. [CrossRef]

21. Yu, S.; Lee, Y.; Oh, S.; Cho, H.; Oda, Y.; Bae, J. Reinforcing effects of different fibers on denture base resin based on the fiber type, concentration, and combination. Dent. Mater. J. 2012, 31, 1039-1046. [CrossRef]

22. Ladizesky, N.; Cheng, Y.; Chow, T.; Ward, I. Acrylic resin reinforced with chopped high performance polyethylene fiber-properties and denture construction. Dent. Mater. 1993, 9, 128-135. [CrossRef]

23. Ghafari, T.; Hamedi, R.F.; Ezzati, B. Does addition of silver nanoparticles to denture base resin increase its thermal conductivity? J. Dent. Sch. 2014, 32, 144.

24. Hamedi-Rad, F.; Ghaffari, T.; Rezaii, F.; Ramazani, A. Effect of nanosilver on thermal and mechanical properties of acrylic base complete dentures. J. Dent. (Tehran) 2014, 11, 495-505.

25. Jasim, B.S.; Ismail, I.J. The effect of silanized alumina nano-fillers addition on some physical and mechanical properties of heat cured polymethyl methacrylate denture base material. J. Baghdad Coll. Dent. 2014, 26, 18-23. [CrossRef]

26. Chaijareenont, P.; Takahashi, H.; Nishiyama, N.; Arksornnukit, M. Effect of different amounts of 3-methacryloxypropyltrimethoxysilane on the flexural properties and wear resistance of alumina reinforced PMMA. Dent. Mater. J. 2012, 31, 623-628. [CrossRef] [PubMed]

27. Tham, W.; Chow, W.; Ishak, Z.M. Simulated body fluid and water absorption effects on poly (methyl methacrylate)/hydroxyapatite denture base composites. Express Polym. Lett. 2010, 4, 517-528. [CrossRef]

28. Aldabib, J.M.; Ishak, Z.A.M. Effect of hydroxyapatite filler concentration on mechanical properties of poly (methyl methacrylate) denture base. SN Appl. Sci. 2020, 2, 1-14. [CrossRef]

29. De Souza Leão, R.; de Moraes, S.L.D.; de Luna Gomes, J.M.; Lemos, C.A.A.; da Silva Casado, B.G.; do Egito Vasconcelos, B.C.; Pellizzer, E.P. Influence of addition of zirconia on PMMA: A systematic review. Mater. Sci. Eng. C 2020, 106, 110292.

30. Zidan, S.; Silikas, N.; Haider, J.; Alhotan, A.; Jahantigh, J.; Yates, J. Evaluation of equivalent flexural strength for complete removable dentures made of zirconia-impregnated PMMA nanocomposites. Materials 2020, 13, 2580. [CrossRef]

31. Gad, M.M.; Rahoma, A.; Al-Thobity, A.M.; ArRejaie, A.S. Influence of incorporation of ZrO2 nanoparticles on the repair strength of polymethyl methacrylate denture bases. Int. J. Nanomed. 2016, 11, 5633-5643. [CrossRef] 
32. Salih, S.I.; Oleiwi, J.K.; Hamad, Q.A. Investigation of fatigue and compression strength for the PMMA reinforced by different system for denture applications. Int. J. Biomed. Mater. Res. 2015, 3, 5-13. [CrossRef]

33. Gad, M.M.A.; Abualsaud, R.; Al-Thobity, A.M.; Almaskin, D.F.; AlZaher, Z.A.; Abushowmi, T.H.; Qaw, M.S.; Akhtar, S.; Al-Harbi, F.A. Effect of $\mathrm{SiO}_{2}$ nanoparticles addition on the flexural strength of repaired acrylic denture base. Eur. J. Dent. 2020, 14, 019-023. [CrossRef]

34. Safi, I.N. Evaluation the effect of nano-fillers $\left(\mathrm{TiO}_{2}, \mathrm{Al}_{2} \mathrm{O}_{3}, \mathrm{SiO}_{2}\right)$ addition on glass transition temperature, E-Moudulus and coefficient of thermal expansion of acrylic denture base material. J. Baghdad Coll. Dent. 2014, 26, 37-41. [CrossRef]

35. Balos, S.; Puskar, T.; Potran, M.; Milekic, B.; Djurovic Koprivica, D.; Laban Terzija, J.; Gusic, I. Modulus, strength and cytotoxicity of PMMA-silica nanocomposites. Coatings 2020, 10, 583. [CrossRef]

36. Balos, S.; Pilic, B.; Markovic, D.; Pavlicevic, J.; Luzanin, O. Poly (methyl-methacrylate) nanocomposites with low silica addition. J. Prosthet. Dent. 2014, 111, 327-334. [CrossRef] [PubMed]

37. Alamgir, M.; Mallick, A.; Nayak, G.; Tiwari, S.K. Development of PMMA/TiO 2 nanocomposites as excellent dental materials. J. Mech. Sci. Technol. 2019, 33, 4755-4760. [CrossRef]

38. Wang, R.; Tao, J.; Yu, B.; Dai, L. Characterization of multiwalled carbon nanotube-polymethyl methacrylate composite resins as denture base materials. J. Prosthet. Dent. 2014, 111, 318-326. [CrossRef]

39. Qasim, S.B.; Al Kheraif, A.A.; Ramakrishaniah, R. An investigation into the impact and flexural strength of light cure denture resin reinforced with carbon nanotubes. World Appl. Sci. J. 2012, 18, 808-812.

40. Mahmood, W.S. The effect of incorporating carbon nanotubes on impact, transverse strength, hardness, and roughness to high impact denture base material. J. Baghdad Coll. Dent. 2015, 27, 96-99. [CrossRef]

41. Turagam, N.; Prasad Mudrakola, D. Effect of micro-additions of carbon nanotubes to polymethylmethacrylate on reduction in polymerization shrinkage. J. Prosthodont. Implant. Esthet. Reconstr. Dent. 2013, 22, 105-111. [CrossRef]

42. Wang, R.; Kayacan, R.; Küçükeşmen, C. Nanotubes/polymethyl methacrylate composite resins as denture base materials. In Carbon Nanomaterials for Biomedical Applications; Springer: Berlin/Heidelberg, Germany, 2016; pp. 227-240.

43. Andreopoulos, A.; Papanicolaou, G. Rubber-modified polymer composites. J. Mater. Sci. 1987, 22, 3417-3420. [CrossRef]

44. Redtenbacher, J. Ueber die zerlegungsprodukte des glyceryloxydes durch trockene destillation. Justus Liebigs Ann. Chem. 1843, 47, 113-148. [CrossRef]

45. Rueggeberg, F.A. From vulcanite to vinyl, a history of resins in restorative dentistry. J. Prosthet. Dent. 2002, 87, 364-379. [CrossRef] [PubMed]

46. Neher, H.T. Acrylic resins. Ind. Eng. Chem. 1936, 28, 267-271. [CrossRef]

47. Peyton, F.A. History of resins in dentistry. Dent. Clin. North Am. 1975, 19, 211-222. [PubMed]

48. DiMaio, F.R. The science of bone cement: A historical review. Orthopedics 2002, 25, 1399-1407.

49. Kraft, J. Polymethylmethacrylate-A review. J. Foot Surg. 1977, 16, 66-68.

50. Frazer, R.Q.; Byron, R.T.; Osborne, P.B.; West, K.P. PMMA: An essential material in medicine and dentistry. J. Long. Term. Eff. Med. 2005, 15, 629-639. [CrossRef]

51. Zidan, S.; Silikas, N.; Alhotan, A.; Haider, J.; Yates, J. Investigating the mechanical properties of ZrO2-impregnated PMMA nanocomposite for denture-based applications. Materials 2019, 12, 1344. [CrossRef]

52. Chen, S.; Yang, J.; Jia, Y.; Lu, B.; Ren, L. TiO2 and PEEK reinforced 3D printing PMMA composite resin for dental denture base applications. Nanomaterials 2019, 9, 1049. [CrossRef]

53. Shakeri, F.; Nodehi, A.; Atai, M. PMMA/double-modified organoclay nanocomposites as fillers for denture base materials with improved mechanical properties. J. Mech. Behav. Biomed. Mater. 2019, 90, 11-19. [CrossRef]

54. Najeeb, S.; Khurshid, Z.; Agwan, A.S.; Zafar, M.S.; Alrahabi, M.; Qasim, S.B.; Sefat, F. Dental applications of nanodiamonds. Sci. Adv. Mater. 2016, 8, 2064-2070. [CrossRef]

55. Johnson, W.W. The history of prosthetic dentistry. J. Prosthet. Dent. 1959, 9, 841-846. [CrossRef]

56. Gautam, R.; Singh, R.D.; Sharma, V.P.; Siddhartha, R.; Chand, P.; Kumar, R. Biocompatibility of polymethylmethacrylate resins used in dentistry. J. Biomed. Mater. Res. Part B 2012, 100, 1444-1450. [CrossRef] [PubMed]

57. Khindria, S.; Mittal, S.; Sukhija, U. Evolution of denture base materials. J. Indian Prosthodont. Soc. $2009,9,64$. 
58. Kedjarune, U.; Charoenworaluk, N.; Koontongkaew, S. Release of methyl methacrylate from heat-curved and autopolymerized resins: Cytotoxicity testing related to residual monomer. Aust. Dent. J. 1999, 44, 25-30. [CrossRef] [PubMed]

59. Lang, B.R. The use of gold in construction of mandibular denture bases. J. Prosthet. Dent. 1974, 32, 398-404. [CrossRef]

60. Murray, M.D.; Darvell, B.W. The evolution of the complete denture base. Theories of complete denture retention-A review. Part 1. Aust. Dent. J. 1993, 38, 216-219. [CrossRef]

61. Komal, L.; Mahesh, V. 19th century denture base materials revisited. Off. Publ. Am. Acad. Hist. Dent. 2011, 59, 1-11.

62. Young, B.C. A Comparison of Polymeric Denture Base Materials. Ph.D. Thesis, University of Glasgow, Glasgow, UK, 2010.

63. Sasaki, H.; Hamanaka, I.; Takahashi, Y.; Kawaguchi, T. Effect of long-term water immersion or thermal shock on mechanical properties of high-impact acrylic denture base resins. Dent. Mater. J. 2016, 35, 204-209. [CrossRef]

64. Takahashi, Y.; Hamanaka, I.; Shimizu, H. Flexural properties of denture base resins subjected to long-term water immersion. Acta Odontol. Scand. 2013, 71, 716-720. [CrossRef]

65. Narva, K.K.; Lassila, L.V.; Vallittu, P.K. The static strength and modulus of fiber reinforced denture base polymer. Dent. Mater. 2005, 21, 421-428. [CrossRef]

66. Nejatian, T.; Nathwani, N.; Taylor, L.; Sefat, F. Denture base composites: Effect of surface modified nano-and micro-particulates on mechanical properties of polymethyl methacrylate. Materials 2020, 13, 307. [CrossRef] [PubMed]

67. Gad, M.M.; Abualsaud, R.; Al-Thobity, A.M.; Baba, N.Z.; Al-Harbi, F.A. Influence of addition of different nanoparticles on the surface properties of poly (methylmethacrylate) denture base material. J. Prosthodont. 2020, 29, 422-428. [CrossRef] [PubMed]

68. Gad, M.M.; Rahoma, A.; Abulsaud, R.; Al-Thobity, A.M.; Akhtar, S.; Helal, M.A.; AL-Harbi, F.A. Impact of different surface treatments and repair material reinforcement on the flexural strength of repaired PMMA denture base material. Dent. Mater. J. 2020, 2018-2436. [CrossRef] [PubMed]

69. Al-Harbi, F.A.; Abdel-Halim, M.S.; Gad, M.M.; Fouda, S.M.; Baba, N.Z.; AlRumaih, H.S.; Akhtar, S. Effect of nanodiamond addition on flexural strength, impact strength, and surface roughness of PMMA denture base. J. Prosthodont. 2019, 28, e417-e425. [CrossRef] [PubMed]

70. Elshereksi, N.; Muchtar, A.; Azhari, C. Effects of nanobarium titanate on physical and mechanical properties of poly (methyl methacrylate) denture base nanocomposites. Polym. Polym. Compos. 2020. [CrossRef]

71. Raszewski, Z.; Nowakowska-Toporowska, A.; Weżgowiec, J.; Nowakowska, D.; Więckiewicz, W. Influence of silanized silica and silanized feldspar addition on the mechanical behavior of polymethyl methacrylate resin denture teeth. J. Prosthet. Dent. 2020, 123, 647.e1-647.e7. [CrossRef]

72. Abushowmi, T.H.; AlZaher, Z.A.; Almaskin, D.F.; Qaw, M.S.; Abualsaud, R.; Akhtar, S.; Al-Thobity, A.M.; Al-Harbi, F.A.; Gad, M.M.; Baba, N.Z. Comparative effect of glass fiber and nano-filler addition on denture repair strength. J. Prosthodont. 2020, 29, 261-268. [CrossRef]

73. Alqahtani, M. Effect of hexagonal boron nitride nanopowder reinforcement and mixing methods on physical and mechanical properties of self-cured PMMA for dental applications. Materials 2020, 13, 2323. [CrossRef]

74. Helal, M.A.; Yang, B.; Saad, E.; Abas, M.; Al-kholy, M.R.; Imam, A.Y.; Gad, M.M. Effect of $\mathrm{SiO}_{2}$ and $\mathrm{Al}_{2} \mathrm{O}_{3}$ nanoparticles on wear resistance of PMMA acrylic denture teeth. Braz. Dent. Sci. 2020, 23, 12.

75. Jagger, D.; Harrison, A.; Jandt, K. The reinforcement of dentures. J. Oral Rehabil. 1999, 26, 185-194. [CrossRef]

76. Alhareb, A.; Akil, H.; Ahmad, Z. Mechanical properties of PMMA denture base reinforced by nitrile rubber particles with $\mathrm{Al}_{2} \mathrm{O}_{3} /$ YSZ fillers. Procedia Manuf. 2015, 2, 301-306. [CrossRef]

77. Ali, U.; Karim, K.J.B.A.; Buang, N.A. A Review of the properties and applications of poly (methyl methacrylate) (PMMA). Polym. Rev. 2015, 55, 678-705. [CrossRef]

78. Anusavice, K.J.; Shen, C.; Rawls, H.R. Phillips' Science of Dental Materials; Elsevier Health Sciences: Amsterdam, The Netherlands, 2012.

79. Swaney, A.C.; Paffenbarger, G.C.; Caul, H.J.; Sweeney, W. American dental association specification No. 12 for denture base resin: Second revision. J. Am. Dent. Assoc. 1953, 46, 54-66. [CrossRef] [PubMed]

80. Council on dental materials and devices. Revised american dental association specification no. 12 for denture base polymers. J. Am. Dent. Assoc. 1975, 90, 451-458. [CrossRef] 
81. ISO. ISO 20795-1:2013 Dentistry-Base Polymers-Part 1: Denture Base Polymers. Available online: https: //www.iso.org/standard/62277.html (accessed on 5 October 2020).

82. Alla, R.; Raghavendra, K.; Vyas, R.; Konakanchi, A. Conventional and contemporary polymers for the fabrication of denture prosthesis: Part I-overview, composition and properties. Int. J. Appl. Dent. Sci. 2015, 1,82 .

83. Harrison, A.; Huggett, R. Effect of the curing cycle on residual monomer levels of acrylic resin denture base polymers. J. Dent. 1992, 20, 370-374. [CrossRef]

84. Bartoloni, J.; Murchison, D.; Wofford, D.; Sarkar, N. Degree of conversion in denture base materials for varied polymerization techniques 1. J. Oral Rehabil. 2000, 27, 488-493. [CrossRef]

85. Jerolimov, V.; Brooks, S.; Huggett, R.; Bates, J. Rapid curing of acrylic denture-base materials. Dent. Mater. 1989, 5, 18-22. [CrossRef]

86. Memon, M.S.; Yunus, N.; Razak, A.A.A.; Memon, M.; Yunus, N.; Razak, A. Some mechanical properties of a highly cross-linked, microwave-polymerized, injection-molded denture base polymer. Int. J. Prosthodont. 2001, 14, 214-218.

87. Tandon, R.; Gupta, S.; Agarwal, S.K. Denture base materials: From past to future. Indian J. Dent. Sci. 2010, 2, 33-39.

88. McCabe, J.F.; Walls, A. Applied Dental Materials; John Wiley and Sons: Chichester, UK, 2013.

89. van Noort, R. The future of dental devices is digital. Dent. Mater. 2012, 28, 3-12. [CrossRef] [PubMed]

90. Alqahtani, M. Mechanical properties enhancement of self-cured PMMA reinforced with zirconia and boron nitride nanopowders for high-performance dental materials. J. Mech. Behav. Biomed. Mater. 2020, 110, 103937. [CrossRef] [PubMed]

91. Shintani, H.; Inoue, T.; Yamaki, M. Analysis of camphorquinone in visible light-cured composite resins. Dent. Mater. 1985, 1, 124-126. [CrossRef]

92. Park, Y.J.; Chae, K.H.; Rawls, H.R. Development of a new photoinitiation system for dental light-cure composite resins. Dent. Mater. 1999, 15, 120-127. [CrossRef]

93. Ogle, R.E.; Sorensen, S.E.; Lewis, E.A. A new visible light-cured resin system applied to removable prosthodontics. J. Prosthet. Dent. 1986, 56, 497-506. [CrossRef]

94. Takamata, T.; Setcos, J.C. Resin denture bases: Review of accuracy and methods of polymerization. Int. J. Prosthodont. 1989, 2, 555-562.

95. Skinner, E.W. Acrylic denture base materials: Their physical properties and manipulation. J. Prosthet. Dent. 1951, 1, 161-167. [CrossRef]

96. Nogueira, S.S.; Ogle, R.E.; Davis, E.L. Comparison of accuracy between compression-and injection-molded complete dentures. J. Prosthet. Dent. 1999, 82, 291-300. [CrossRef]

97. Gharechahi, J.; Asadzadeh, N.; Shahabian, F.; Gharechahi, M. Dimensional changes of acrylic resin denture bases: Conventional versus injection-molding technique. J. Dent. (Tehran) 2014, 11, 398-405.

98. Zafar, M.S.; Ahmed, N. Nanoindentation and surface roughness profilometry of poly methyl methacrylate denture base materials. Technol. Health Care 2014, 22, 573-581. [CrossRef]

99. Vallittu, P.K.; Miettinen, V.; Alakuijala, P. Residual monomer content and its release into water from denture base materials. Dent. Mater. 1995, 11, 338-342. [CrossRef]

100. Elwakiel, N.; El-Sayed, Y.; Elkafrawy, H. Synthesis, Characterization of Ag and Sn2 complexes and their applications to improve the biological and mechanical properties of denture base materials. J. Mol. Struct. 2020, 1219, 128521. [CrossRef]

101. Raszewski, Z. Influence of polymerization method on the cytotoxicity of three different denture base acrylic resins polymerized in different methods. Saudi J. Biol. Sci. 2020, 27, 2612-2616. [CrossRef] [PubMed]

102. Zheng, J.; Su, Q.; Wang, C.; Cheng, G.; Zhu, R.; Shi, J.; Yao, K. Synthesis and biological evaluation of PMMA/MMT nanocomposite as denture base material. J. Mater. Sci. Mater. Med. 2011, 22, 1063-1071. [CrossRef]

103. Soygun, K.; Bolayir, G.; Boztug, A. Mechanical and thermal properties of polyamide versus reinforced PMMA denture base materials. J. Adv. Prosthodont. 2013, 5, 153-160. [CrossRef]

104. Asar, N.V.; Albayrak, H.; Korkmaz, T.; Turkyilmaz, I. Influence of various metal oxides on mechanical and physical properties of heat-cured polymethyl methacrylate denture base resins. J. Adv. Prosthodont. 2013, 5, 241-247. [CrossRef] 
105. Polychronakis, N.; Dimitriadi, M.; Ioannidis, A.; Papadopoulos, T. The effect of different cooling procedures on mechanical properties of denture base materials measured by instrumented indentation testing. J. Prosthodont. Res. 2020, 64, 326-331. [CrossRef]

106. Rickman, L.J.; Padipatvuthikul, P.; Satterthwaite, J.D. Contemporary denture base resins: Part 1. Dent. Update 2012, 39, 25-30. [CrossRef]

107. Mark, J.E. Physical Properties of Polymers Handbook, 1076; Springer: New York, NY, USA, 2007; pp. 3-8.

108. Kutz, M. Handbook of Materials Selection; John Wiley and Sons: Hoboken, NJ, USA, 2002; p. 341.

109. Braun, K.N.; Mello, J.N.; Rached, R.; Del Bel Cury, A. Surface texture and some properties of acrylic resins submitted to chemical polishing. J. Oral Rehabil. 2003, 30, 91-98. [CrossRef]

110. Jorge, J.H.; Giampaolo, E.T.; Machado, A.L.; Vergani, C.E. Cytotoxicity of denture base acrylic resins: A literature review. J. Prosthet. Dent. 2003, 90, 190-193. [CrossRef]

111. Lung, C.; Darvell, B. Minimization of the inevitable residual monomer in denture base acrylic. Dent. Mater. 2005, 21, 1119-1128. [CrossRef] [PubMed]

112. Thaitammayanon, C.; Sirichompun, C.; Wiwatwarrapan, C. Ultrasonic treatment reduced residual monomer in methyl methacrylate-based orthodontic base-plate materials. Dent. Oral. Craniofac. Res. 2018, 4, 1-5. [CrossRef]

113. Vallittu, P.K.; Ruyter, I.E.; Buykuilmaz, S. Effect of polymerization temperature and time on the residual monomer content of denture base polymers. Eur. J. Oral Sci. 1998, 106, 588-593. [CrossRef]

114. Doğan, A.; Bek, B.; Cevik, N.; Usanmaz, A. The effect of preparation conditions of acrylic denture base materials on the level of residual monomer, mechanical properties and water absorption. J. Dent. 1995, 23, 313-318. [CrossRef]

115. Leggat, P.A.; Kedjarune, U. Toxicity of methyl methacrylate in dentistry. Int. Dent. J. 2003, 53, $126-131$. [CrossRef]

116. Latief, A. Sorption and Solubility of a Denture Base Acrylic. Master's Thesis, Cape Peninsula University of Technology, Cape Town, South Africa, 2012.

117. Miettinen, V.M.; Vallittu, P.K. Water sorption and solubility of glass fiber-reinforced denture polymethyl methacrylate resin. J. Prosthet. Dent. 1997, 77, 531-534. [CrossRef]

118. Bayraktar, G.; Guvener, B.; Bural, C.; Uresin, Y. Influence of polymerization method, curing process, and length of time of storage in water on the residual methyl methacrylate content in dental acrylic resins. J. Biomed. Mater. 2006, 76, 340-345. [CrossRef]

119. Tuna, S.H.; Keyf, F.; Gumus, H.O.; Uzun, C. The evaluation of water sorption/solubility on various acrylic resins. Eur. J. Dent. 2008, 2, 191-197. [CrossRef]

120. Saini, R.; Kotian, R.; Madhyastha, P.; Srikant, N. Comparative study of sorption and solubility of heat-cure and self-cure acrylic resins in different solutions. Indian J. Dent. Res. 2016, 27, 288-294.

121. Van Noort, R.; Barbour, M.E. Introduction to Dental Materials 4; Elsevier Health Sciences: Amsterdam, The Netherlands, 2013.

122. Sagsoz, N.P.; Yanıkoglu, N.; Ulu, H.; Bayındır, F. Color changes of polyamid and polymetyhl methacrylate denture base materials. Open J. Stomatol. 2014, 4, 489-496. [CrossRef]

123. Alp, G.; Johnston, W.M.; Yilmaz, B. Optical properties and surface roughness of prepolymerized poly (methyl methacrylate) denture base materials. J. Prosthet. Dent. 2019, 121, 347-352. [CrossRef] [PubMed]

124. Scotti, R.; Mascellani, S.C.; Forniti, F. The in vitro color stability of acrylic resins for provisional restorations. Int. J. Prosthodont. 1997, 10, 164-168. [PubMed]

125. Ganzarolli, S.M.; Nunes de Mello, J.A.; Shinkai, R.S.; Del Bel Cury, A. A Internal adaptation and some physical properties of methacrylate-based denture base resins polymerized by different techniques. J. Biomed. Mater. 2007, 82, 169-173. [CrossRef] [PubMed]

126. Safarabadi, M.; Khansari, N.; Rezaei, A. An experimental investigation of $\mathrm{HA} / \mathrm{AL}_{2} \mathrm{O}_{3}$ nanoparticles on mechanical properties of restoration materials. Eng. Solid Mech. 2014, 2, 173-182. [CrossRef]

127. Chandler, H.; Bowen, R.; Paffenbarger, G. Development of a radiopaque denture base material. J. Biomed. Mater. Res. 1971, 5, 253-265. [CrossRef]

128. McCabe, J.; Wilson, H. A radio-opaque denture material. J. Dent. 1976, 4, 211-217. [CrossRef]

129. Aldabib, J. Reinforcement of poly (methyl methacrylate) denture base material. Dent. Med. J. 2020, 2, 46-53.

130. Lang, L.A.; Mattie, P.A.; Rawis, H.R. The effect of triphenylbismuth on the radiopacity and performance properties of compression-and injection-molded denture resins. J. Prosthodont. 2000, 9, 23-29. [CrossRef] 
131. Alhareb, A.; Akil, H.; Ahmad, Z. Influence of $\mathrm{Al}_{2} \mathrm{O}_{3} / \mathrm{Y}-\mathrm{TSZ}$ mixture as filler loading on the radiopacity of PMMA denture base composites. Procedia Chem. 2016, 19, 646-650. [CrossRef]

132. Mattie, P.A.; Rawls, H.R.; Cabasso, I. Development of a radiopaque, autopolymerizing dental acrylic resin. J. Prosthodont. 1994, 3, 213-218. [CrossRef]

133. Bloodworth, K.E.; Render, P.J. Dental acrylic resin radiopacity: Literature review and survey of practitioners' attitudes. J. Prosthet. Dent. 1992, 67, 121-123. [CrossRef]

134. Bangera, M.K.; Kotian, R.; Ravishankar, N. Effect of titanium dioxide nanoparticle reinforcement on flexural strength of denture base resin: A systematic review and meta-analysis. Jpn. Dent. Sci. Rev. 2020, 56, 68-76. [CrossRef] [PubMed]

135. AlQahtani, M.; Haralur, S.B. Influence of different repair acrylic resin and thermocycling on the flexural strength of denture base resin. Medicina 2020, 56, 50. [CrossRef] [PubMed]

136. Kawaguchi, T.; Lassila, L.V.; Baba, H.; Tashiro, S.; Hamanaka, I.; Takahashi, Y.; Vallittu, P.K. Effect of cellulose nanofiber content on flexural properties of a model, thermoplastic, injection-molded, polymethyl methacrylate denture base material. J. Mech. Behav. Biomed. Mater. 2020, 102, 103513. [CrossRef] [PubMed]

137. Hannon, S.A.; Hussain, W.A.; Hussain, S.M. Studying the impact strength of layered denture base resin. Iraqi J. Phys. 2020, 18, 25-32. [CrossRef]

138. Vallittu, P.K.; Vojtkova, H.; Lassila, V.P. Impact strength of denture polymethyl methacrylate reinforced with continuous glass fibers or metal wire. Acta Odontol. Scand. 1995, 53, 392-396. [CrossRef]

139. Mowade, T.K.; Dange, S.P.; Thakre, M.B.; Kamble, V.D. Effect of fiber reinforcement on impact strength of heat polymerized polymethyl methacrylate denture base resin: In vitro study and SEM analysis. J. Adv. Prosthodont. 2012, 4, 30-36. [CrossRef]

140. Faot, F.; Costa, M.A.; Cury, A.A.D.B.; Garcia, R.C.R. Impact strength and fracture morphology of denture acrylic resins. J. Prosthet. Dent. 2006, 96, 367-373. [CrossRef]

141. Abdulrazzaq Naji, S.; Behroozibakhsh, M.; Jafarzadeh Kashi, T.S.; Eslami, H.; Masaeli, R.; Mahgoli, H.; Tahriri, M.; Ghavvami Lahiji, M.; Rakhshan, V. Effects of incorporation of 2.5 and $5 \mathrm{wt} \% \mathrm{TiO} 2$ nanotubes on fracture toughness, flexural strength, and microhardness of denture base poly methyl methacrylate (PMMA). J. Adv. Prosthodont. 2018, 10, 113-121. [CrossRef]

142. Abdel-Karim, U.M.; Kenawy, E.S. Synthesis of zirconia, organic and hybrid nanofibers for reinforcement of polymethyl methacrylate denture base: Evaluation of flexural strength and modulus, fracture toughness and impact strength. Tanta Dent. J. 2019, 16, 12-20.

143. Mousavi, A.; Aliha, M.; Imani, D. Effects of biocompatible nanofillers on mixed-mode I and II fracture toughness of PMMA base dentures. J. Mech. Behav. Biomed. Mater. 2020, 103, 103566. [CrossRef] [PubMed]

144. Ali, I.L.; Yunus, N.; Abu-Hassan, M.I. Hardness, flexural strength, and flexural modulus comparisons of three differently cured denture base systems. J. Prosthodont. 2008, 17, 545-549. [CrossRef] [PubMed]

145. Vojdani, M.; Bagheri, R.; Khaledi, A.A.R. Effects of aluminum oxide addition on the flexural strength, surface hardness, and roughness of heat-polymerized acrylic resin. J. Dent. Sci. 2012, 7, 238-244. [CrossRef]

146. Barbosa, D.B.; Souza, R.F. d.; Pero, A.C.; Marra, J.; Compagnoni, M.A. Flexural strength of acrylic resins polymerized by different cycles. J. Appl. Oral Sci. 2007, 15, 424-428. [CrossRef]

147. Zappini, G.; Kammann, A.; Wachter, W. Comparison of fracture tests of denture base materials. J. Prosthet. Dent. 2003, 90, 578-585. [CrossRef]

148. Stafford, G.; Huggett, R.; Causton, B. Fracture toughness of denture base acrylics. J. Biomed. Mater. Res. 1980, 14, 359-371. [CrossRef]

149. Robinson, J.; McCabe, J. Impact strength of acrylic resin denture base materials with surface defects. Dent. Mater. 1993, 9, 355-360. [CrossRef]

150. Zafar, M.S. Wear behavior of various dental restorative materials. Mater. Technol. 2018, 33, 25-31. [CrossRef]

151. Zafar, M.S.; Ahmed, N. Effects of wear on hardness and stiffness of restorative dental materials. Life Sci. J. 2014, 11, 11-18.

152. Zafar, M.S.; Amin, F.; Fareed, M.A.; Ghabbani, H.; Riaz, S.; Khurshid, Z.; Kumar, N. Biomimetic aspects of restorative dentistry biomaterials. Biomimetics 2020, 5, 34. [CrossRef]

153. Gupta, A.; Kamra, M. An evaluation of the effect of water sorption on dimensional stability of the acrylic resin denture bases. Int. J. Contemp. Dent. 2011, 2.

154. Arima, T.; Murata, H.; Hamad, T. The effects of cross-linking agents on the water sorption and solubility characteristics of denture base resin. J. Oral Rehabil. 1996, 23, 476-480. [CrossRef] [PubMed] 
155. Anonymous. Dental Materials and their Selection; Quintessence: Chicago, IL, USA; London, UK, $2002 ;$ p. 418.

156. Atwood, D.A. Bone loss of edentulous alveolar ridges. J. Periodontol. 1979, 50, 11-21. [CrossRef] [PubMed]

157. Alsaggaf, A.; Fenlon, M.R. A case control study to investigate the effects of denture wear on residual alveolar ridge resorption in edentulous patients. J. Dent. 2020, 103373. [CrossRef] [PubMed]

158. Atsu, S.; KeskIn, Y. Effect of silica coating and silane surface treatment on the bond strength of soft denture liner to denture base material. J. Appl. Oral Sci. 2013, 21, 300-306. [CrossRef] [PubMed]

159. Nowakowska-Toporowska, A.; Raszewski, Z.; Wieckiewicz, W. Color change of soft silicone relining materials after storage in artificial saliva. J. Prosthet. Dent. 2016, 115, 377-380. [CrossRef] [PubMed]

160. Cavalcanti, Y.W.; Bertolini, M.M.; Cury, A.A.D.B.; da Silva, W.J. The effect of poly (methyl methacrylate) surface treatments on the adhesion of silicone-based resilient denture liners. J. Prosthet. Dent. 2014, 112, 1539-1544. [CrossRef]

161. Bail, M.; Jorge, J.H.; Urban, V.M.; Campanha, N.H. Surface roughness of acrylic and silicone-based soft liners: In vivo study in a rat model. J. Prosthodont. 2014, 23, 146-151. [CrossRef]

162. Habib, S.R.; Vohra, F.A. Replacing existing dentures by copy-denture technique for geriatric patients: A case report. J. Pak. Dent. Assoc. 2013, 22, 265-270.

163. Patil, S.; Naveen, B.; Patil, N. Bonding acrylic teeth to acrylic resin denture bases: A review. Gerodontology 2006, 23, 131-139. [CrossRef]

164. Huggett, R.; John, G.; Jagger, R.G.; Bates, J.F. Strength of the acrylic denture base tooth bond. Br. Dent. J. 1982, 153, 187-190. [CrossRef] [PubMed]

165. Darbar, U.; Huggett, R.; Harrison, A. Denture fracture-A survey. Br. Dent. J. 1994, 176, 342-345. [CrossRef] [PubMed]

166. Chung, K.; Chung, C.; Chung, C.; Chan, D. Effect of pre-processing surface treatments of acrylic teeth on bonding to the denture base. J. Oral Rehabil. 2008, 35, 268-275. [CrossRef] [PubMed]

167. Saavedra, G.; Valandro, L.F.; Leite, F.P.P.; Amaral, R.; Özcan, M.; Bottino, M.A.; Kimpara, E.T. Bond strength of acrylic teeth to denture base resin after various surface conditioning methods before and after thermocycling. Int. J. Prosthodont. 2007, 20, 199-201.

168. Goldin, E.B.; Boyd III, N.W.; Goldstein, G.R.; Hittelman, E.L.; Thompson, V.P. Marginal fit of leucite-glass pressable ceramic restorations and ceramic-pressed-to-metal restorations. J. Prosthet. Dent. 2005, 93, $143-147$. [CrossRef]

169. Alabdulkader, M.A.; Habib, S.R. Effect of cement application techniques on the adaptation and retention of provisional crowns. Technol. Health Care 2018, 26, 945-955. [CrossRef]

170. Alt, V.; Hannig, M.; Wöstmann, B.; Balkenhol, M. Fracture strength of temporary fixed partial dentures: CAD/CAM versus directly fabricated restorations. Dent. Mater. 2011, 27, 339-347. [CrossRef]

171. Yilmaz, A.; Baydas, S. Fracture resistance of various temporary crown materials. J. Contemp. Dent. Pract. 2007, 8, 44-51. [CrossRef]

172. Kwon, S.; Park, Y.; Jun, S.; Ahn, J.; Lee, I.; Cho, B.; Son, H.; Seo, D. Thermal irritation of teeth during dental treatment procedures. Restor. Dent. Endod. 2013, 38, 105-112. [CrossRef]

173. Bahrani, F.; Safari, A.; Vojdani, M.; Karampoor, G.; Patil, S. Comparison of hardness and surface roughness of two denture bases polymerized by different methods. World J. Dent. 2012, 3, 171-175. [CrossRef]

174. Haas, S.; Brauer, G.; Dickson, G. A characterization of polymethylmethacrylate bone cement. J. Bone Jt. Surg. 1975, 57, 380-391. [CrossRef]

175. Alkurt, M.; Duymuş, Z.Y.; Gundogdu, M. Effect of repair resin type and surface treatment on the repair strength of heat-polymerized denture base resin. J. Prosthet. Dent. 2014, 111, 71-78. [CrossRef] [PubMed]

176. Raszewski, Z.; Nowakowska, D. Mechanical properties of hot curing acrylic resin after reinforced with different kinds of fibers. Int. J. Biomed. Mat. Res. 2013, 1, 9-13. [CrossRef]

177. Polyzois, G.L.; Andreopoulos, A.G.; Lagouvardos, P.E. Acrylic resin denture repair with adhesive resin and metal wires: Effects on strength parameters. J. Prosthet. Dent. 1996, 75, 381-387. [CrossRef]

178. Polyzois, G.L.; Tarantili, P.A.; Frangou, M.J.; Andreopoulos, A.G. Fracture force, deflection at fracture, and toughness of repaired denture resin subjected to microwave polymerization or reinforced with wire or glass fiber. J. Prosthet. Dent. 2001, 86, 613-619. [CrossRef] [PubMed]

179. Al Baker, A.; Habib, S.R.; Al Amri, M.D. Preserving esthetics, occlusion and occlusal vertical dimension in a patient with fixed prostheses seeking dental implant treatment. Saudi Dent. J. 2016, 28, 203-208. [CrossRef] 
180. Agarwal, M.; Nayak, A.; Hallikerimath, R. A study to evaluate the transverse strength of repaired acrylic denture resins with conventional heat-cured, autopolymerizing and microwave-cured resins: An in vitro study. J. Indian Prosthodont. Soc. 2008, 8, 36-41. [CrossRef]

181. Faot, F.; Da Silva, W.J.; Da Rosa, R.S.; Del Bel Cury, A.A.; Garcia, R.C.M.R. Strength of denture base resins repaired with auto-and visible light-polymerized materials. J. Prosthodont. Dent. 2009, 18, 496-502. [CrossRef]

182. Murphy, W.; Huggett, R.; Handley, R.; Brooks, S. Rigid cold curing resins for direct use in the oral cavity. Br. Dent. J. 1986, 160, 391-394. [CrossRef]

183. Shifman, A. Clinical applications of visible light-cured resin in maxillofacial prosthetics. part I: Denture base and reline material. J. Prosthet. Dent. 1990, 64, 578-582. [CrossRef]

184. Fellman, S. Visible light-cured denture resin used in making dentures with conventional teeth. J. Prosthet. Dent. 1989, 62, 356-359. [CrossRef]

185. Polyzois, G.L.; Handley, R.W.; Stafford, G.D. Repair strength of denture base resins using various methods. Eur. J. Prosthodont. Restor. Dent. 1995, 3, 183-186. [PubMed]

186. Jacobsen, N.L.; Mitchell, D.L.; Johnson, D.L.; Holt, R.A. Lased and sandblasted denture base surface preparations affecting resilient liner bonding. J. Prosthet. Dent. 1997, 78, 153-158. [CrossRef]

187. Jagger, R.G.; al-Athel, M.S.; Jagger, D.C.; Vowles, R.W. Some variables influencing the bond strength between PMMA and a silicone denture lining material. Int. J. Prosthodont. 2002, 15, 55-58.

188. Vojdani, M.; Rezaei, S.; Zareeian, L. Effect of chemical surface treatments and repair material on transverse strength of repaired acrylic denture resin. Indian J. Dent. Res. 2008, 19, 2-5. [CrossRef]

189. Vallittu, P.K.; Lassila, V.P.; Lappalainen, R. Wetting the repair surface with methyl methacrylate affects the transverse strength of repaired heat-polymerized resin. J. Prosthet. Dent. 1994, 72, 639-643. [CrossRef]

190. Minami, H.; Suzuki, S.; Minesaki, Y.; Kurashige, H.; Tanaka, T. In vitro evaluation of the influence of repairing condition of denture base resin on the bonding of autopolymerizing resins. J. Prosthet. Dent. 2004, 91, 164-170. [CrossRef]

191. Seó, R.S.; Neppelenbroek, K.H.; Filho, J.N.A. Factors affecting the strength of denture repairs. J. Prosthodont. 2007, 16, 302-310. [CrossRef]

192. Ahmed, Z.U.; Flynn, J.; Riedel, E.R.; Huryn, J.M.; Rosen, E.B. Definitive maxillary obturator prosthesis: Timelines for fabrication and follow-up. Spec. Care Dent. 2020, 40, 315-319. [CrossRef]

193. Molinero-Mourelle, P.; Helm, A.; Cobo-Vázquez, C.; Lam, W.Y.; Azevedo, L.; Pow, E.H.; Gómez-Polo, M. Treatment outcomes of implant-supported maxillary obturator prostheses in patients with maxillary defects: A systematic review. Int. J. Prosthodont. 2020, 33, 429-440. [CrossRef]

194. Urechescu, H.; Pricop, M.; Bogdan, L.; Nes, C.S.; Pricop, C.; Rusu, L.C.; Rivis, M. Experimental compression and traction tests on heat-cured pmma used in maxillary obturator prostheses. Mat. Plast 2016, 53, 76.

195. Urechescu, H.; Pricop, M.; Pricop, C.; Mateas, M.; Natanael, S.; Galatanu, S.V. Thermoplastic materials used for fabrication of maxillary obturator prostheses. Mat. Plast 2017, 54, 477. [CrossRef]

196. Metwaly, A.F.; Taha, E.R. Evaluation of microbial adhesions and quality of life in maxillectomy patients rehabilitated with cobalt-chromium and thermoplastic obturators. Egypt. Dent. J. 2017, 63, 3639-3650. [CrossRef]

197. Koyama, S.; Kato, H.; Harata, T.; Sasaki, K. A workflow for fabricating a hollow obturator by using 3D digital technologies. J. Prosthet. Dent. 2020, 123, 648-652. [CrossRef] [PubMed]

198. Jang, W.; Lim, H.; Yun, K.; Park, C.; Yang, H. Fabrication of closed hollow obturator for hard palate defect patient undergone maxillectomy. J. Korean Acad. Prosthodont. 2020, 58, 30-34. [CrossRef]

199. Sharma, P.; Mago, G. Rehabilitation of patient with hemimaxillectomy defect using a closed hollow bulb obturator: A case report. J. Adv. Med. Dent. Sci. Res. 2020, 8, 107-110.

200. Ramasamy, T.V.; Chandra, J. An innovative sectional silicone obturator in a patient with partial maxillectomy: A Case report. J. Indian. Prosthodont. Soc. 2020, 20, 115-119. [CrossRef]

201. Qoran, A.H.; Aminifar, S.; Adli, A.R.; Abachizadeh, H. Using a silicone core to reduce the weight of maxillary obturator prosthesis. J. Dent. Sch. 2012, 30, 136-142.

202. Bidra, A.S.; Taylor, T.D.; Agar, J.R. Computer-aided technology for fabricating complete dentures: Systematic review of historical background, current status, and future perspectives. J. Prosthet. Dent. 2013, 109, 361-366. [CrossRef]

203. Alp, G.; Murat, S.; Yilmaz, B. Comparison of Flexural Strength of Different CAD/CAM PMMA-Based Polymers. J. Prosthodont. 2019, 28, 491-495. [CrossRef] 
204. Al-Dwairi, Z.N.; Tahboub, K.Y.; Baba, N.Z.; Goodacre, C.J. A comparison of the flexural and impact strengths and flexural modulus of CAD/CAM and conventional heat-cured polymethyl methacrylate (PMMA). J. Prosthodont. 2020, 29, 341-349. [CrossRef] [PubMed]

205. Arslan, M.; Murat, S.; Alp, G.; Zaimoglu, A. Evaluation of flexural strength and surface properties of prepolymerized CAD/CAM PMMA-based polymers used for digital 3D complete dentures. Int. J. Comput. Dent. 2018, 21, 31-40. [PubMed]

206. Al-Dwairi, Z.N.; Tahboub, K.Y.; Baba, N.Z.; Goodacre, C.J.; Özcan, M. A comparison of the surface properties of CAD/CAM and conventional polymethylmethacrylate (PMMA). J. Prosthodont. 2019, 28, 452-457. [CrossRef] [PubMed]

207. Murat, S.; Alp, G.; Alatalı, C.; Uzun, M. In vitro evaluation of adhesion of candida albicans on CAD/CAM PMMA-based polymers. J. Prosthodont. 2019, 28, 873-879. [CrossRef] [PubMed]

208. Srinivasan, M.; Gjengedal, H.; Cattani-Lorente, M.; Moussa, M.; Durual, S.; Schimmel, M.; Müller, F. CAD/CAM milled complete removable dental prostheses: An in vitro evaluation of biocompatibility, mechanical properties, and surface roughness. Dent. Mater. J. 2018, 2017-2207. [CrossRef] [PubMed]

209. Choi, J.J.E.; Uy, C.E.; Plaksina, P.; Ramani, R.S.; Ganjigatti, R.; Waddell, J.N. Bond Strength of denture teeth to heat-cured, CAD/CAM and 3D printed denture acrylics. J. Prosthodont. 2020, 29, 415-421. [CrossRef] [PubMed]

210. Kalberer, N.; Mehl, A.; Schimmel, M.; Müller, F.; Srinivasan, M. CAD-CAM milled versus rapidly prototyped (3D-printed) complete dentures: An in vitro evaluation of trueness. J. Prosthet. Dent. 2019, 121, 637-643. [CrossRef]

211. Davda, K.; Osnes, C.; Dillon, S.; Wu, J.; Hyde, T.; Keeling, A. An investigation into the trueness and precision of copy denture templates produced by rapid prototyping and conventional means. Eur. J. Prosthodont. Restor. Dent. 2017, 25, 186-192.

212. Steinmassl, P.; Wiedemair, V.; Huck, C.; Klaunzer, F.; Steinmassl, O.; Grunert, I.; Dumfahrt, H. Do CAD/CAM dentures really release less monomer than conventional dentures? Clin. Oral Investig. 2017, 21, 1697-1705. [CrossRef]

213. Quirynen, M.; Marechal, M.; Busscher, H.; Weerkamp, A.; Darius, P.; van Steenberghe, D. The influence of surface free energy and surface roughness on early plaque formation: An in vivo study in man. J. Clin Periodontol. 1990, 17, 138-144. [CrossRef]

214. Quirynen, M.v.; Van Der Mei, H.; Bollen, C.; Schotte, A.; Marechal, M.; Doornbusch, G.; Naert, I.; Busscher, H. v.; Van Steenberghe, D. An in vivo study of the influence of the surface roughness of implants on the microbiology of supra-and subgingival plaque. J. Dent. Res. 1993, 72, 1304-1309. [CrossRef] [PubMed]

215. Iqbal, Z.; Zafar, M.S. Role of antifungal medicaments added to tissue conditioners: A systematic review. J. Prosthodont. Res. 2016, 60, 231-239. [CrossRef] [PubMed]

216. Gendreau, L.; Loewy, Z.G. Epidemiology and etiology of denture stomatitis. J. Prosthodont. 2011, 20, 251-260. [CrossRef] [PubMed]

217. Hoshi, N.; Mori, H.; Taguchi, H.; Taniguchi, M.; Aoki, H.; Sawada, T.; Kawabata, M.; Kuwabara, A.; Oono, A.; Tanaka, K.; et al. Management of oral candidiasis in denture wearers. J. Prosthodont. Res. 2011, 55, 48-52. [CrossRef]

218. de Oliveira, C.E.; Gasparoto, T.H.; Dionisio, T.J.; Porto, V.C.; Vieira, N.A.; Santos, C.F.; Lara, V.S. Candida albicans and denture stomatitis: Evaluation of its presence in the lesion, prosthesis, and blood. Int. J. Prosthodont. 2010, 23, 158-159.

219. Amin, W.M.; Al-Ali, M.H.; Salim, N.A.; Al-Tarawneh, S.K. A new form of intraoral delivery of antifungal drugs for the treatment of denture-induced oral candidosis. Eur. J. Dent. 2009, 3, 257-266. [CrossRef]

220. Huettig, F.; Prutscher, A.; Goldammer, C.; Kreutzer, C.A.; Weber, H. First clinical experiences with CAD/CAM-fabricated PMMA-based fixed dental prostheses as long-term temporaries. Clin. Oral Investig. 2016, 20, 161-168. [CrossRef]

221. Moshkelgosha, V.; Shomali, M.; Momeni, M.A.S.O.O.M.E.H. Comparison of wear resistance of hawley and vacuum formed retainers: An in-vitro study. J. Dent. Biomater. 2016, 3, 248-253.

222. Casey, J.; Dunn, W.J.; Wright, E. In vitro wear of various orthotic device materials. J. Prosthet. Dent. 2003, 90, 498-502. [CrossRef]

223. Rantala, L.; Lastumäki, T.; Peltomäki, T.; Vallittu, P. Fatigue resistance of removable orthodontic appliance reinforced with glass fibre weave. J. Oral Rehabil. 2003, 30, 501-506. [CrossRef] 
224. Faltermeier, A.; Rosentritt, M.; Müssig, D. Acrylic removable appliances: Comparative evaluation of different postpolymerization methods. Am. J. Orthod. Dentofac. Orthop. 2007, 131, 301.e16-301.e22. [CrossRef] [PubMed]

225. Namura, Y.; Takamizawa, T.; Uchida, Y.; Inaba, M.; Noma, D.; Takemoto, T.; Miyazaki, M.; Motoyoshi, M. Effects of composition on the hardness of orthodontic adhesives. J. Oral Sci. 2020, 62, 48-51. [CrossRef] [PubMed]

226. Habib, S.R.; Azad, A.A. Comparison of patient's satisfaction with replacement complete dentures fabricated by copy denture technique versus conventional technique. J. Pak. Dent. Assoc. 2009, 18, 9-13.

227. Habib, S.R.; Al Ajmi, M.G.; Al Dhafyan, M.; Jomah, A.; Abualsaud, H.; Almashali, M. Effect of margin designs on the marginal adaptation of zirconia copings. Acta Stomatol. Croat. 2017, 51, 179-187. [CrossRef]

228. Habib, S.R.; Ali, M.; Al Hossan, A.; Majeed-Saidan, A.; Al Qahtani, M. Effect of cementation, cement type and vent holes on fit of zirconia copings. Saudi Dent. J. 2019, 31, 45-51. [CrossRef]

229. Zafar, M.S.; Al-Samadani, K.H. Potential use of natural silk for bio-dental applications. J. Taibah Univ. Med. Sci. 2014, 9, 171-177. [CrossRef]

230. Tsuchiya, H.; Hoshino, Y.; Tajima, K.; Takagi, N. Leaching and cytotoxicity of formaldehyde and methyl methacrylate from acrylic resin denture base materials. J. Prosthet. Dent. 1994, 71, 618-624. [CrossRef]

231. Nandal, S.; Ghalaut, P.; Shekhawat, H.; Gulati, M.S. New era in denture base resins: A review. Dent. J. Adv. Stud. 2013, 1, 136-143. [CrossRef]

232. Cierech, M.; Osica, I.; Kolenda, A.; Wojnarowicz, J.; Szmigiel, D.; Łojkowski, W.; Kurzydłowski, K.; Ariga, K.; Mierzwińska-Nastalska, E. Mechanical and physicochemical properties of newly formed ZnO-PMMA nanocomposites for denture bases. Nanomaterials 2018, 8, 305. [CrossRef]

233. Khan, A.S.; Azam, M.T.; Khan, M.; Mian, S.A.; Rehman, I.U. An update on glass fiber dental restorative composites: A systematic review. Mater. Sci. Eng. C 2015, 47, 26-39. [CrossRef]

234. Xu, H.; Schumacher, G.E.; Eichmiller, F.; Peterson, R.; Antonucci, J.M.; Mueller, H. Continuous-fiber preform reinforcement of dental resin composite restorations. Dent. Mater. 2003, 19, 523-530. [CrossRef]

235. Petersen, R.C. Discontinuous fiber-reinforced composites above critical length. J. Dent. Res. 2005, 84, 365-370. [CrossRef] [PubMed]

236. Hyer, M.W.; White, S.R. Stress Analysis of Fiber-Reinforced Composite Materials; DEStech Publications, Inc.: Lancaster, PA, USA, 2009.

237. van Heumen, C.C.; Kreulen, C.M.; Bronkhorst, E.M.; Lesaffre, E.; Creugers, N.H. Fiber-reinforced dental composites in beam testing. Dent. Mater. 2008, 24, 1435-1443. [CrossRef]

238. Butterworth, C.; Ellakwa, A.E.; Shortall, A. Fibre-reinforced composites in restorative dentistry. Dent. Update 2003, 30, 300-306. [CrossRef]

239. Garoushi, S.; Vallittu, P.K.; Lassila, L.V. Depth of cure and surface microhardness of experimental short fiber-reinforced composite. Acta Odontol. Scand. 2008, 66, 38-42. [CrossRef] [PubMed]

240. Topouzi, M.; Kontonasaki, E.; Bikiaris, D.; Papadopoulou, L.; Paraskevopoulos, K.M.; Koidis, P. Reinforcement of a PMMA resin for interim fixed prostheses with silica nanoparticles. J. Mech. Behav. Biomed. Mater. 2017, 69, 213-222. [CrossRef]

241. Ratanajanchai, M.; Kanchanavasita, W.; Suputtamongkol, K.; Wonglamsam, A.; Thamapipol, S.; Sae-Khow, O. Heat-cured poly(methyl methacrylate) resin incorporated with different food preservatives as an anti-microbial denture base material. J. Dent. Sci. 2020. [CrossRef]

242. DeBoer, J.; Vermilyea, S.; Brady, R. The effect of carbon fiber orientation on the fatigue resistance and bending properties of two denture resins. J. Prosthet. Dent. 1984, 51, 119-121. [CrossRef]

243. Alla, R.K.; Sajjan, S.; Alluri, V.R.; Ginjupalli, K.; Upadhya, N. Influence of fiber reinforcement on the properties of denture base resins. J. Biomater. Nanobiotechnol. 2013, 4, 91. [CrossRef]

244. Kanie, T.; Fujii, K.; Arikawa, H.; Inoue, K. Flexural properties and impact strength of denture base polymer reinforced with woven glass fibers. Dent. Mater. 2000, 16, 150-158. [CrossRef]

245. John, J.; Gangadhar, S.A.; Shah, I. Flexural strength of heat-polymerized polymethyl methacrylate denture resin reinforced with glass, aramid, or nylon fibers. J. Prosthet. Dent. 2001, 86, 424-427. [CrossRef] [PubMed]

246. Ladizesky, N.H.; Chow, T.W.; Cheng, Y.Y. Denture base reinforcement using woven polyethylene fiber. Int. J. Prosthodont. 1994, 7, 307-314. [PubMed]

247. Ladizesky, N.H.; Ho, C.F.; Chow, T.W. Reinforcement of complete denture bases with continuous high performance polyethylene fibers. J. Prosthet. Dent. 1992, 68, 934-939. [CrossRef] 
248. Singh, K.; Sharma, S.K.; Negi, P.; Kumar, M.; Rajpurohit, D.; Khobre, P. Comparative evaluation of flexural strength of heat polymerised denture base resins after reinforcement with glass fibres and nylon fibres: An in vitro study. Adv. Hum. Biol. 2016, 6, 91. [CrossRef]

249. Farina, A.P.; Cecchin, D.; Soares, R.G.; Botelho, A.L.; Takahashi, J.M.F.K.; Mazzetto, M.O.; Mesquita, M.F. Evaluation of vickers hardness of different types of acrylic denture base resins with and without glass fibre reinforcement. Gerodontology 2012, 29, 155-160. [CrossRef]

250. Vallittu, P.K. A review of fiber-reinforced denture base resins. J. Prosthodont. 1996, 5, 270-276. [CrossRef]

251. Chong, K.; Chai, J. Strength and mode of failure of unidirectional and bidirectional glass fiber-reinforced composite materials. Int. J. Prosthodont. 2003, 16, 161-166.

252. McDonough, W.G.; Antonucci, J.M.; Dunkers, J.P. Interfacial shear strengths of dental resin-glass fibers by the microbond test. Dent. Mater. 2001, 17, 492-498. [CrossRef]

253. Matinlinna, J.P.; Lassila, L.V.; Özcan, M.; Yli-Urpo, A.; Vallittu, P.K. An introduction to silanes and their clinical applications in dentistry. Int. J. Prosthodont. 2004, 17, 155-164.

254. Nejatian, T.; Johnson, A.; Van Noort, R. Reinforcement of denture base resin. In Advances in Science and Technology; Trans Tech Publ: Zurich, Switzerland, 2006; Volume 49, pp. 124-129.

255. Kul, E.; Aladă̆, L.İ; Yesildal, R. Evaluation of thermal conductivity and flexural strength properties of poly (methyl methacrylate) denture base material reinforced with different fillers. J. Prosthet. Dent. 2016, 116, 803-810. [CrossRef]

256. Mansour, M.M.; Wagner, W.C.; Chu, T.G. Effect of mica reinforcement on the flexural strength and microhardness of polymethyl methacrylate denture resin. J. Prosthodont. 2013, 22, 179-183. [CrossRef]

257. Casemiro, L.A.; Martins, C.H.G.; Pires-de-Souza, F.d.C.; Panzeri, H. Antimicrobial and mechanical properties of acrylic resins with incorporated silver-zinc zeolite-Part I. Gerodontology 2008, 25, 187-194. [CrossRef] [PubMed]

258. Flores, J.C.; Garcia, R.; Villanueva, G.; Acosta-Torres, L. Antimicrobial poly (methyl methacrylate) with silver nanoparticles for dentistry: A systematic review. Appl. Sci. 2020, 10, 4007.

259. Kurt, A.; Erkose-Genc, G.; Uzun, M.; Emrence, Z.; Ustek, D.; Isik-Ozkol, G. The antifungal activity and cytotoxicity of silver containing denture base material. Niger. J. Clin. Pract. 2017, 20, 290-295. [CrossRef] [PubMed]

260. Acosta-Torres, L.S.; Mendieta, I.; Nunez-Anita, R.E.; Cajero-Juarez, M.; Castano, V.M. Cytocompatible antifungal acrylic resin containing silver nanoparticles for dentures. Int. J. Nanomed. 2012, 7, 4777-4786.

261. Monteiro, D.R.; Gorup, L.F.; Takamiya, A.S.; de Camargo, E.R.; Filho, A.C.R.; Barbosa, D.B. Silver distribution and release from an antimicrobial denture base resin containing silver colloidal nanoparticles. J. Prosthodont. 2012, 21, 7-15. [CrossRef]

262. Sawada, T.; Sawada, T.; Kumasaka, T.; Hamada, N.; Shibata, T.; Nonami, T.; Kimoto, K. Self-cleaning effects of acrylic resin containing fluoridated apatite-coated titanium dioxide. Gerodontology 2014, 31, 68-75. [CrossRef]

263. Shibata, T.; Hamada, N.; Kimoto, K.; Sawada, T.; Sawada, T.; Kumada, H.; Umemoto, T.; Toyoda, M. Antifungal effect of acrylic resin containing apatite-coated TiO2 photocatalyst. Dent. Mater. J. 2007, 26, 437-444. [CrossRef]

264. Al-Bakri, I.; Harty, D.; Al-Omari, W.; Swain, M.; Chrzanowski, W.; Ellakwa, A. Surface characteristics and microbial adherence ability of modified polymethylmethacrylate by fluoridated glass fillers. Aust. Dent. J. 2014, 59, 482-489. [CrossRef]

265. Tsutsumi, C.; Takakuda, K.; Wakabayashi, N. Reduction of Candida biofilm adhesion by incorporation of prereacted glass ionomer filler in denture base resin. J. Dent. 2016, 44, 37-43. [CrossRef]

266. Lee, J.; El-Fiqi, A.; Jo, J.; Kim, D.; Kim, S.; Jun, S.; Kim, H.; Lee, H. Development of long-term antimicrobial poly (methyl methacrylate) by incorporating mesoporous silica nanocarriers. Dent. Mater. 2016, 32, 1564-1574. [CrossRef]

267. Alwan, S.A.; Alameer, S.S. The effect of the addition of silanized nano titania fillers on some physical and mechanical properties of heat cured acrylic denture base materials. J. Baghdad Coll. Dent. 2015, 325, 1-12. [CrossRef]

268. Bacali, C.; Badea, M.; Moldovan, M.; Sarosi, C.; Nastase, V.; Baldea, I.; Chiorean, R.S.; Constantiniuc, M. The influence of graphene in improvement of physico-mechanical properties in PMMA denture base resins. Materials 2019, 12, 2335. [CrossRef] 
269. Zafar, M.S.; Alnazzawi, A.A.; Alrahabi, M.; Fareed, M.A.; Najeeb, S.; Khurshid, Z. Nanotechnology and nanomaterials in dentistry. In Advanced Dental Biomaterials; Khurshid, Z., Najeeb, S., Zafar, M.S., Sefat, F., Eds.; Woodhead Publishing: Cambridge, UK, 2019; pp. 477-505.

270. Yu, W.; Wang, X.; Tang, Q.; Guo, M.; Zhao, J. Reinforcement of denture base PMMA with $\mathrm{ZrO}_{2}$ nanotubes. J. Mech. Behav. Biomed. Mater. 2014, 32, 192-197. [CrossRef]

271. Yadav, P.; Mittal, R.; Sood, V.K.; Garg, R. Effect of incorporation of silane-treated silver and aluminum microparticles on strength and thermal conductivity of PMMA. J. Prosthodont. 2012, 21, 546-551. [CrossRef]

272. Aljafery, A.; MAH, B. Effect of addition $\mathrm{ZrO}_{2}-\mathrm{Al}_{2} \mathrm{O}_{3}$ nanoparticles mixture on some properties and denture base adaptation of heat cured acrylic resin denture base material. J. Baghdad Coll. Dent. 2015, 325, 1-15.

273. Muklif, O.R.; Ismail, I.J. Studying the effect of addition a composite of silanized Nano- $\mathrm{Al}_{2} \mathrm{O}_{3}$ and plasma treated polypropylene fibers on some physical and mechanical properties of heat cured PMMA denture base material. J. Baghdad Coll. Dent. 2015, 325, 1-13. [CrossRef]

274. Khurshid, Z.; Zafar, M.; Qasim, S.; Shahab, S.; Naseem, M.; AbuReqaiba, A. Advances in nanotechnology for restorative dentistry. Materials 2015, 8, 717-731. [CrossRef]

275. Hari Prasad, A.; Kalavathy, M.; Mohammed, H. Effect of glass fiber and silane treated glass fiber reinforcement on impact strength of maxillary complete denture. Ann. Essen. Dent. 2011, 4, 7-12. [CrossRef]

276. Salman, T.A.; Khalaf, H.A. The influence of adding of modified $\mathrm{ZrO} 2-\mathrm{TiO} 2$ nanoparticles on certain physical and mechanical properties of heat polymerized acrylic resin. J. Baghdad Coll. Dent. 2015, 325, 1-15.

277. Abdulkareem, M.M.; Hatim, N.A. Evaluation the biological effect of adding aluminum oxide, silver nanoparticles into microwave treated PMMA powder. Int. J. Enhanc. Res. Sci. Technol. Eng. 2015, 4, 172-178.

278. Bian, Y.M.; Zhang, X.Y.; Zhu, B.S.; Yu, W.Q.; Ruan, D.P.; Min, M. Influence of different amount of silane coupling agent on the flexural strength of PMMA/nanometer ZrO2 composites. Shanghai J. Stomatol. 2007, 16, 319-323.

279. Asopa, V.; Suresh, S.; Khandelwal, M.; Sharma, V.; Asopa, S.S.; Kaira, L.S. A comparative evaluation of properties of zirconia reinforced high impact acrylic resin with that of high impact acrylic resin. Saudi J. Dent. Res. 2015, 6, 146-151. [CrossRef]

280. Ahmed, M.A.; El-Shennawy, M.; Althomali, Y.M.; Omar, A.A. Effect of titanium dioxide nano particles incorporation on mechanical and physical properties on two different types of acrylic resin denture base. World J. Nano. Sci. Eng. 2016, 6, 111-119. [CrossRef]

281. Elshereksi, N.; Mohamed, S.; Arifin, A.; Mohd Ishak, Z. Effect of filler incorporation on the fracture toughness properties of denture base poly (methyl methacrylate). J. Phys. Sci. 2009, 20, 1-12.

282. Protopapa, P.; Kontonasaki, E.; Bikiaris, D.; Paraskevopoulos, K.M.; Koidis, P. Reinforcement of a PMMA resin for fixed interim prostheses with nanodiamonds. Dent. Mater. J. 2011, 30, 222-231. [CrossRef]

283. Mangal, U.; Kim, J.; Seo, J.; Kwon, J.; Choi, S. Novel poly (methyl methacrylate) containing nanodiamond to improve the mechanical properties and fungal resistance. Materials 2019, 12, 3438. [CrossRef]

284. Fouda, S.M.; Gad, M.M.; Ellakany, P.; Al-Thobity, A.M.; Al-Harbi, F.A.; Virtanen, J.I.; Raustia, A. The effect of nanodiamonds on candida albicans adhesion and surface characteristics of PMMA denture base material-an in vitro study. J. Appl. Oral Sci. 2019, 27, 20180779. [CrossRef]

285. McNally, T.; Pötschke, P.; Halley, P.; Murphy, M.; Martin, D.; Bell, S.E.J.; Brennan, G.P.; Bein, D.; Lemoine, P.; Quinn, J.P. Polyethylene multiwalled carbon nanotube composites. Polymer 2005, 46, 8222-8232. [CrossRef]

286. Collins, P.G.; Avouris, P. Nanotubes for electronics. Sci. Am. 2000, 283, 62-69. [CrossRef]

287. Rodford, R. Further development and evaluation of high impact strength denture base materials. J. Dent. 1990, 18, 151-157. [CrossRef]

288. Delfi, M.; Ghomi, M.; Zarrabi, A.; Mohammadinejad, R.; Taraghdari, Z.B.; Ashrafizadeh, M.; Zare, E.N.; Agarwal, T.; Padil, V.V.; Mokhtari, B. Functionalization of polymers and nanomaterials for biomedical applications: Antimicrobial platforms and drug carriers. Prosthesis 2020, 2, 117-139. [CrossRef]

289. Rouabhia, M.; Chmielewski, W. Diseases associated with oral polymicrobial biofilms. Open Mycol. J. 2012, 6, 27-32. [CrossRef]

290. Makvandi, P.; Gu, J.T.; Zare, E.N.; Ashtari, B.; Moeini, A.; Tay, F.R.; Niu, L. Polymeric and inorganic nanoscopical antimicrobial fillers in dentistry. Acta Biomater. 2020, 101, 69-101. [CrossRef]

291. Akihiro Yoshihara, D.; Sakuma, P.S.; Kobayashi, P.S.; Miyazaki, P.H. Antimicrobial effect of fluoride mouthrinse on mutans streptococci and lactobacilli in saliva. Pediatr. Dent. 2001, 23, 113-117. 
292. Gad, M.M.; Al-Thobity, A.M.; Fouda, S.M.; Näpänkangas, R.; Raustia, A. Flexural and surface properties of PMMA denture base material modified with thymoquinone as an antifungal agent. J. Prosthodont. 2020, 29, 243-250. [CrossRef]

293. Makvandi, P.; Jamaledin, R.; Jabbari, M.; Nikfarjam, N.; Borzacchiello, A. Antibacterial quaternary ammonium compounds in dental materials: A systematic review. Dent. Mater. 2018, 34, 851-867. [CrossRef]

294. Makvandi, P.; Ghaemy, M.; Mohseni, M. Synthesis and characterization of photo-curable bis-quaternary ammonium dimethacrylate with antimicrobial activity for dental restoration materials. Eur. Polym. J. 2016, 74, 81-90. [CrossRef]

295. Makvandi, P.; Ghaemy, M.; Ghadiri, A.; Mohseni, M. Photocurable, antimicrobial quaternary ammonium-modified nanosilica. J. Dent. Res. 2015, 94, 1401-1407. [CrossRef]

296. Pesci-Bardon, C.; Fosse, T.; Serre, D.; Madinier, I. In vitro antiseptic properties of an ammonium compound combined with denture base acrylic resin. Gerodontology 2006, 23, 111-116. [CrossRef]

297. Pesci-Bardon, C.; Fosse, T.; Madinier, I.; Serre, D. In vitro new dialysis protocol to assay the antiseptic properties of a quaternary ammonium compound polymerized with denture acrylic resin. Lett. Appl. Microbiol. 2004, 39, 226-231. [CrossRef] [PubMed]

298. Mai, H.; Kim, D.; Hyun, D.C.; Park, J.H.; Lee, S.M.; Lee, D. A new antibacterial agent-releasing polydimethylsiloxane coating for polymethyl methacrylate dental restorations. J. Clin. Med. 2019, 8, 1831. [CrossRef] [PubMed]

299. Lee, J.; Jo, J.; Kim, D.; Patel, K.D.; Kim, H.; Lee, H. Nano-graphene oxide incorporated into PMMA resin to prevent microbial adhesion. Dent. Mater. 2018, 34, 63-72. [CrossRef] [PubMed]

(C) 2020 by the author. Licensee MDPI, Basel, Switzerland. This article is an open access article distributed under the terms and conditions of the Creative Commons Attribution (CC BY) license (http://creativecommons.org/licenses/by/4.0/). 